\title{
The Relationships of
}

Megaoryzomys curioi, an Extinct Cricetine Rodent (Muroidea: Muridae) from the Galápagos Islands, Ecuador
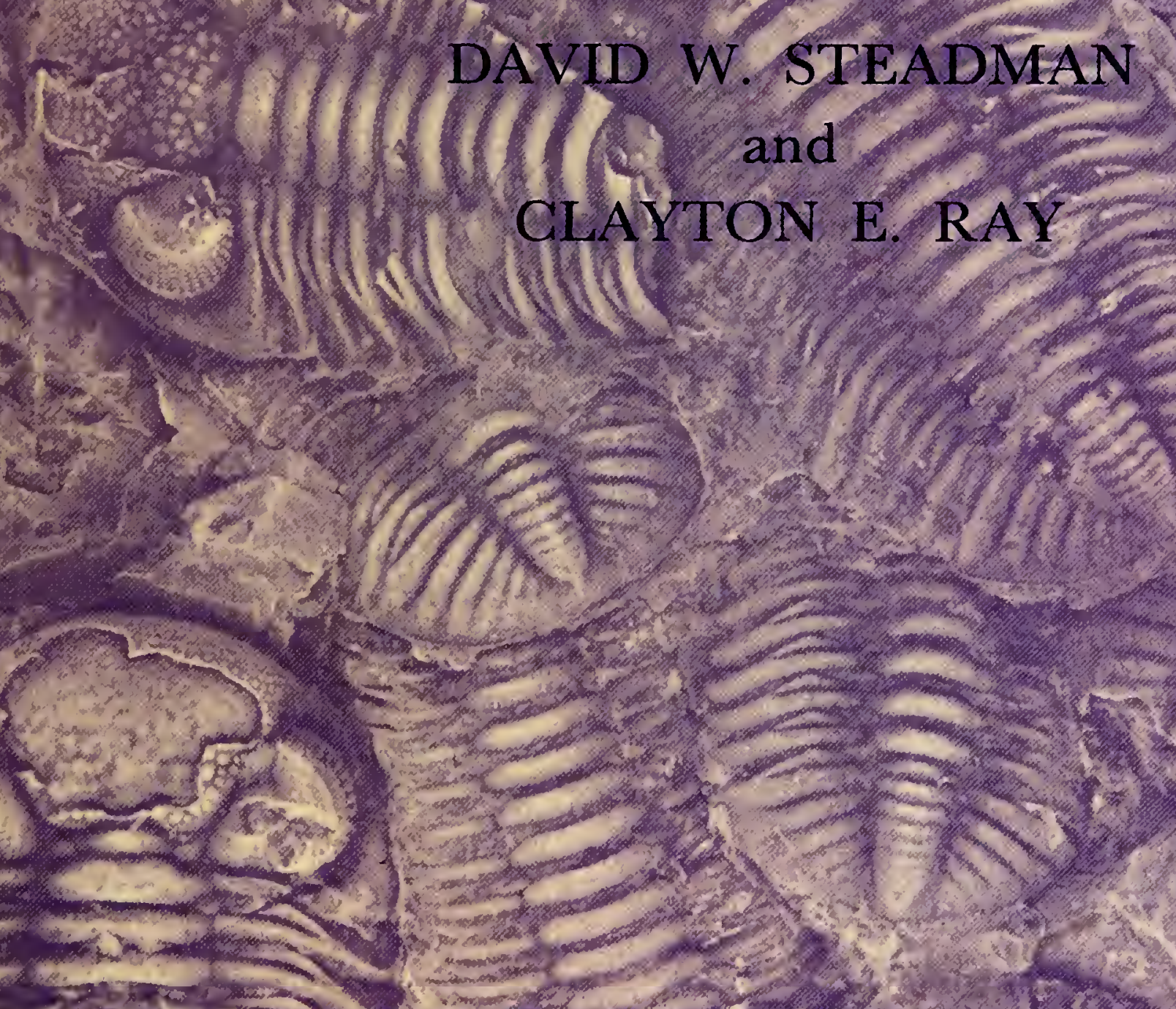

SMITHSONAN CONTRIBUTIONS TO PALEOBIOLOGY * NUMBER 51 


\title{
SERIES PUBLICATIONS OF THE SMITHSONIAN INSTITUTION
}

Emphasis upon publication as a means of "diffusing knowledge" was expressed by the first Secretary of the Smithsonian. In his formal plan for the Institution, Joseph Henry outlined a program that included the following statement: "It is proposed to publish a series of reports, giving an account of the new discoveries in science, and of the changes made from year to year in all branches of knowledge." This theme of basic research has been adhered to through the years by thousands of titles issued in series publications under the Smithsonian imprint, commencing with Smithsonian Contributions to Knowledge in 1848 and continuing with the following active series:

\author{
Smithsonian Contributions to Anthropology \\ Smithsonian Contributions to Astrophysics \\ Smithsonian Contributions to Botany \\ Smithsonian Contributions to the Earth Sciences \\ Smithsonian Contributions to the Marine Sciences \\ Smithsonian Contributions to Paleobiology \\ Smithsonian Contributions to Zoology \\ Smithsonian Studies in Air and Space \\ Smithsonian Studies in History and Technology
}

In these series, the Institution publishes small papers and full-scale monographs that report the research and collections of its various museums and bureaux or of professional colleagues in the world of science and scholarship. The publications are distributed by mailing lists to libraries, universities, and similar institutions throughout the world.

Papers or monographs submitted for series publication are received by the Smithsonian Institution Press, subject to its own review for format and style, only through departments of the various Smithsonian museums or bureaux, where the manuscripts are given substantive review. Press requirements for manuscript and art preparation are outlined on the inside back cover.

S. Dillon Ripley

Secretary

Smithsonian Institution 


\title{
The Relationships of
}

Megaoryzomys curioi, an Extinct Cricetine Rodent (Muroidea: Muridae) from the Galápagos Islands, Ecuador

\author{
David W. Steadman \\ and Clayton E. Ray
}

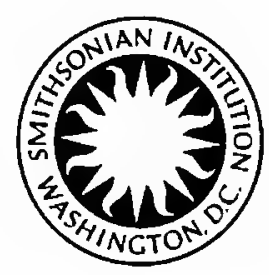

SMITHSONIAN INSTITUTION PRESS

City of Washington 


\section{A B S T R ACT}

Steadman, David W., and Clayton E. Ray. The Relationships of Megaoryzomys curioi, an Extinct Cricetine Rodent (Muroidea: Muridae) from the Galápagos Islands, Ecuador. Smithsonian Contributions to Paleobiology, number 51, 23 pages, 11 figures, 1 table, 1982.-Megaoryzomys curioi is a thomasomyine, not an oryzomyine as previously believed. This rodent was originally described, from three bony fragments found in a cave on Isla Santa Cruz, Galápagos, as a new species of the Antillean oryzomyine genus Megalomys. The genus Megaoryzomys was named recently for this species, based on new material from Isla Santa Cruz. Our study of additional material indicates that Megaoryzomys curioi is not closely related to Oryzomys but is most similar to large species of Thomasomys, a genus confined to mainland South America. The Galápagos have been colonized by cricetine rodents at least three times, once by a thomasomyine and twice by oryzomyines. Of these colonists, Megaoryzomys curioi is the most divergent from mainland relatives and thus is probably derived from the earliest immigrant. Although the time of extinction of Megaoryzomys curioi has not been determined, and it has never been recorded from life, it probably survived into historic time.

Orficial publication date is handstamped in a limited number of initial copies and is recorded in the Institution's annual report, Similhsmian Year. SERIES cover oesicon: The Irilobite l'hacops rana Green.

Library of Congress Cataloging in Publication Data

Steadman, David W.

The relationships of Megaoryzomys curioi, an extinet Ciricetine rodent (Muroidea: Muridae) from the Galápagos Islands, Eeuador.

(Smithsomian contributions to palcobiology ; no. 51)

Bibliography: p.

1. Megaoryzomys curioi. 2. Paleontology-Recent. 3. Paleontology-Galápagos Islands. I. Ray, Clayton Edward. II. Title. III. Series.

QE701.5.56 no. 51 [QE882.R6] 560s $\left|569^{\prime} .3233\right| \quad 82-857$ AAC:R2 


\section{Contents}

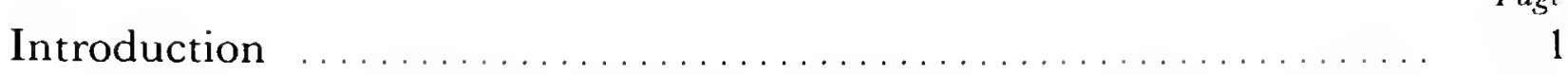

Acknowledgments ................................. 1

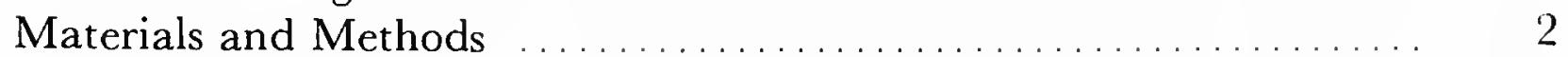

Abbreviations ...................................... 2

Fossil Material ..................................... 3

Recent Comparative Material .......................... 3

Measurements .................................... 5

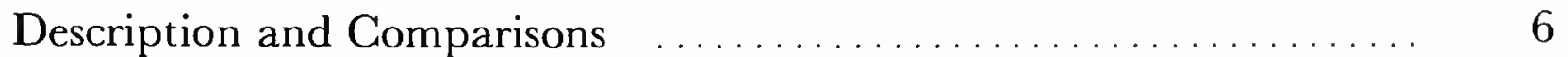

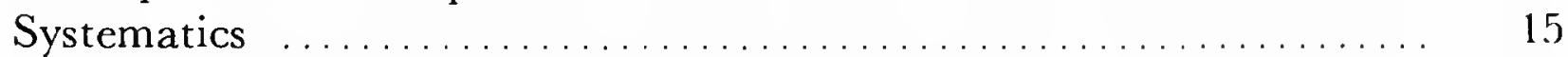

Tribe Thomasomyini ...................................... ${ }^{15}$

Genus Megaoryzomys Lenglet and Coppois, 1979 .............. 15

Megaoryzomys curioi (Niethammer, 1964) .................. 15

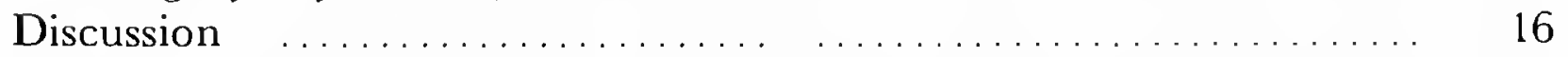

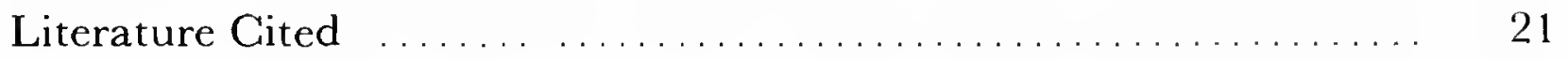





\title{
The Relationships of Megaoryzomys curioi, an Extinct Cricetine Rodent (Muroidea: Muridae) from the Galápagos Islands, Ecuador
}

\author{
David W. Steadman \\ and Clayton E. Ray
}

\section{Introduction}

Megaoryzomys curioi (Niethammer, 1964) is the only species of vertebrate in the Galápagos Islands that is known only from fossils, having neither been seen alive nor collected from life by man. (Nesoryzomys fernandinae Hutterer and Hirsch, 1979, though not collected from life, was described from fresh owl pellets and may have been seen alive.) Megaoryzomys curioi, a muskrat-sized, cricetine rodent, was named on the basis of three bony fragments from a cave on Isla Santa Cruz. It was assigned originally to the Antillean genus Megalomys. The inadequacy of these meager fragments led us to question the validity of the assignment and to try to augment the material; Ray, beginning in 1965, and Steadman, beginning in 1978. The abundant material that resulted from our efforts immediately made it clear that the species required its own, new genus (Ray and Whitmore, 1973).

Early in 1978 we attempted to communicate

David W. Steadman, Department of Vertebrate Zoology, National Museum of Natural History, Smithsonian Institution, Washington, D.C. 20560. Clayton E. Ray, Department of Paleobiology, National Museum of Natural History, Smithsonian Institution, Washington D.C. 20560 . with Dr. Guy Coppois about our long-term project, but we received no response from him; however, during final stages of preparation of this manuscript, we received from Thomas E. Simkin a copy of Lenglet and Coppois (1979), in which the new genus Megaoryzomys was named for Megalomys curioi. We agree with Lenglet and Coppois (1979) that the species curioi was not correctly placed in the genus Megalomys, but we do not agree that its closest affinities are with Oryzomys. Furthermore, we feel that the work of Lenglet and Coppois is otherwise inadequate in its systematic treatment of this rodent. Therefore, we review here the morphology of Megaoryzomys based on new material and present our interpretation of its relationships. Material from Steadman's latest field work of October 1980-January 1981 will be described in his comprehensive work (in prep.) on the vertebrate paleontology of Galápagos, as will the material from Isla Isabela recorded herein as Megaoryzomys species.

Acknow Ledgments.-Field work in Galápagos was supported by the Smithsonian Institution from the Walcott Fund (1968-1969), from the Fluid Research Fund (1966-1967 and 1977-1978, 1980) through the kind efforts of Dr. S. Dillon 
Ripley and Storrs L. Olson, and from the Graduate Student Program Development Fund of the University of Arizona (1980). Funds provided to Ray in 1966-1969 werc used in part to defray nonpaleontological field work under the auspices of the Darwin Foundation, whereas those provided to Steadman were used strictly for paleontological work as directed by the CDRS. Permits for this latter field research were made possible through the offices of the Dirección de Desarrollo Forestal, Ministerio de Agricultura y Ganadería, Quito; Lcdo. Miguel Cifuentes, Intendente of Parque Nacional Galápagos; Craig MacFarland, Hendrick Hoeck, and David Duffy, past directors of the Charles Darwin Research Station; and Peter Kramer, Thomas E. Simkin, G.T. Corley Smith, and David W. Snow of the Charles Darwin Foundation. The personnel of the Parque Nacional Galápagos and the Charles Darwin Research Station made Steadman's field work not only possible but extremely pleasant. Marsha S. Cox, Minard L. Hall, and Thomas E. Simkin provided valuable advice on working in Galápagos. We particularly thank Miguel Pozo, Edward Steadman, and James Hill for working in the field with Steadman in Galápagos. Their companionship, hard work, and knowledge of field techniques aided immcnsely in this project. The De Roy's (André, Jacqueline, and Gil), the Devine's (Bud, Doris, and Steve), and the Moore's (Alan and Tui De Roy) constantly gave all sorts of advice and assistance to Steadman during field work. We also appreciate the field efforts of Srs. Camilo Calapucho, Miguel Castro, André De Roy, Michael Harris, and Tjitte dc Vries, each of whom has collected fossils of Megaoryzomys. The late James L. Peters was instrumental in 1965 in Ray's first efforts to secure adequate material in Galápagos.

Financial support for Steadman's rescarch at the National Museum of Natural History was provided by a Summer Visiting Student fcllowship from the Smithsonian Institution and $\mathrm{Na}$ tional Science Foundation grant DEB-7923840 to Paul S. Martin through the Department of Geosciences, University of Arizona. We thank the personnel of the Division of Birds, Division of
Mammals, and the Department of Paleobiology, NMNH, for the many services and courtesies put forth. Steadman's travel to the $\mathrm{BM}(\mathrm{NH})$ was financed by the National Geographic Society. We thank those in charge of collections of all institutions from which we have been permitted to examine specimens. Most especially, we thank Miss Levitt, Andrew Currant, Anthony J. Sutcliffe, and Cyril A. Walker of the $\mathrm{BM}(\mathrm{NH})$ for allowing us to examine specimens under their care.

We thank W. Vervoort, C. Smeenk, and D.A. Hooijer, for their kindness and patience in connection with the loan of the indispensablc skull of Megalomys desmarestii from the Lciden Museum, and Robert T. Orr of the CAS for the loan of Galápagan oryzomyines.

Discussions with Alfred L. Gardner, Michael D. Carleton, and Charles O. Handley, Jr., have enriched our knowlege of cricetine morphology and systematics. Jon A. Baskin and Michael D. Carleton provided very detailed criticisms of the manuscript. Charles O. Handley, Jr., and Paul S. Martin also read and criticized an carlier version. Naturally none of them is responsible for any remaining shortcomings. Helen F. James provided an English translation of Niethammer (1964). Karena M. Schmidt and Gone Hall helped in the sorting and cleaning of fossils. The drawings of skulls and mandibles were prcparcd by Lawrence B. Isham, on special funds provided by Richard S. Cowan, then director of the $\mathrm{NMNH}$; the drawings of enamel patterns were kindly prepared by Molly Wing, without remuneration. The photographs are by Victor E. Krantz. This is contribution number 295 of the Charles Darwin Foundation.

\section{Materials and Methods}

AbBreviations.- The following are used to denote collections from which specimens were examined.

AMNH American Museum of Natural History, New York

BM(NH) British Museum (Natural History), London 
CAS California Academy of Sciences, San Francisco

CDRS Charles Darwin Research Station, Isla Santa Cruz, Galápagos, Ecuador

CMNH Chicago [Field] Museum of Natural History, Chicago

LSU Louisiana State University, Baton Rouge

UF/FSM Florida State Museum, University of Florida, Gainesville

USNM former United States National Museum specimens deposited in the National Museum of Natural History, Smithsonian Institution

The abbreviation NMNH is used in the text to denote the National Museum of Natural History, Smithsonian Institution, Washington, D.C.

Fossil Material. - Listed below are the specimens of Megaoryzomys curioi and $M$. species examined in this study with their collectors and dates collected. All localities are on Isla Santa Cruz and Isla Isabela (Figures 1 and 2). Except for Cueva de Kubler, Cueva de Iguana, and André's cave, we cannot vouch for the accuracy of the names or exact localities of the fossil sites in Galápagos. ( $\mathrm{MNI}=$ minimum number of individuals represented by specimens listed.)

\section{Megaoryzomys curioi, Isla Santa Cruz}

Cave no. 1 (= cave in Naranja Zone), different places, T. de Vries, 16 Jan 1966

USNM $284279 ; 5$ postcranial specimens; $\mathrm{MNI}=1$

Cave no. 1, T. de Vries, 19 Nov 1966

USNM 284280-284289; 2 maxillae, 2 cranial fragments, 2 dentaries, 1 isolated tooth, 22 postcranial specimens; $\mathrm{MNI}=3$

Gave no. 1, place 2, T. de Vries, 16 Jan 1966

USNM 284295-284318; 1 nearly complete skull, 2 maxillae, 12 dentaries, 6 isolated teeth, 56 postcranial specimens; $\mathrm{MNI}=9$

Cave no. 3, T. de Vries, 17 Jan 1966

USNM 284290-284294; 4 dentaries, 2 isolated teeth, 19 postcranial specimens; $\mathrm{MNI}=3$

Cave no. 4 (= cave north of El Chato), T. de Vries, 21 Nov 1966

USNM 284348; 4 isolated teeth, 8 postcranial specimens; $\mathrm{MNI}=2$

Cave no. 4, T. de Vries, M. Castro, 27 Jul 1967

USNM 284319-284330; 2 maxillae, 4 cranial fragments, 2 dentaries, 18 isolated teeth, approximately 80 postcranial specimens; $\mathrm{MNI}=2$

Cave no. 5 (= cave north of Reserve in Naranja Zone), T. de Vries, 20 Nov 1966

USNM 284331-284335; 4 dentaries, 1 isolated tooth, 2 postcranial specimens; $\mathrm{MNI}=3$
Gave near Bellavista, M. Harris, Oct 1966

CDRS 4-13; 3 dentaries, 1 isolated tooth, 6 postcranial specimens; $\mathrm{MNI}=4$

Cave near Bellavista (not definitely the same cave as above), M. Castro, before Apr 1969

USNM 284336-284347; 1 maxilla, 6 dentaries, 4 isolated teeth, 7 postcranial specimens; $\mathrm{MNI}=4$

Cave in Cascajo Mountains, E. Curio, 1962/1963

$\mathrm{BM}(\mathrm{NH}) 67.1649 ; 1$ maxilla, 2 postcranial specimens; $\mathrm{MNI}=1$

Cueva de Kubler, D. Steadman, M. Pozo, 21, 23, 28 Jul 1979, 3 Aug 19?9

USNM 284197-284270; 1 nearly complete skull, 19 maxillae, 30 cranial fragments, 16 dentaries, 116 isolated teeth, 203 postcranial specimens; $\mathrm{MNI}=12$

Cueva de Iguana, various localities, D. Steadman, M. Pozo, 8-13 Jan 1978, 3-11 Jun 1978, 13-18 Jul 1978

USNM 284271-284278; 1 nearly complete skull, 3 cranial fragments, 1 maxilla, 9 isolated teeth, 18 postcranial specimens; $\mathrm{MNI}=7$

André's Cave, A. De Roy, Mar 1969

CDRS 1-3; 1 nearly complete skull, 1 dentary, 1 postcranial specimen; $\mathrm{MNI}=1$

\section{Megaoryzomys species, Isla Isabela}

Cueva de Sucre (= Cueva de Hueco Sucre), $1 \mathrm{~km}$ north of Pueblo Santo Tomás, M. Castro, Jan 1968

USNM 284349-284357; 2 maxillae, 4 cranial fragments, 3 dentaries, 14 isolated teeth, 8 postcranial specimens; $\mathrm{MNI}=2$

Recent Comparative Material (skulls and mandibles).-Thomasomys aureus, USNM 194818, 194821, 194827 (Perú); T. praetor, CMNH 19255, 19256 (Perú); T. princeps, USNM 251957 (Colombia); T. pyrrhonotus, CMNH 81296, 84438, USNM 304538 (Perú); T. cinereiventer, AMNH 32421, 32423, 32430 (Colombia); $T$. cinereus, CMNH 81309, 81312, 81326, USNM 304537 (Perú); $T$. hylophilus, CMNH 92558, 92560, 92561 (Colombia); T. ischyrus, CMNH 19795, 19799, 19801, USNM 297635 (Perú); T. kalinowskii, CMNH 23723, 23735 (Perú); T. rhoadsi, CMNH 53210, 53211, 93146 (Ecuador); Rhipidomys leucodactylus, USNM 194495, 194496, 194499, 194501 (Perú); R. caucensis, USNM 387922, 387925 (Venezuela); $R$. goodfellowi, USNM 374543, 409937 (Venezuela); $R$. venezuelae, USNM 371247, 442286 (Venezuela); $R$. venustus, USNM 137507, 371242 (Venezuela); Oryzomys palustris, USNM 116531, 178297, 339957, (México, Alabama, Nicaragua); Oryzomys albigularis USNM 137509, 168229, 


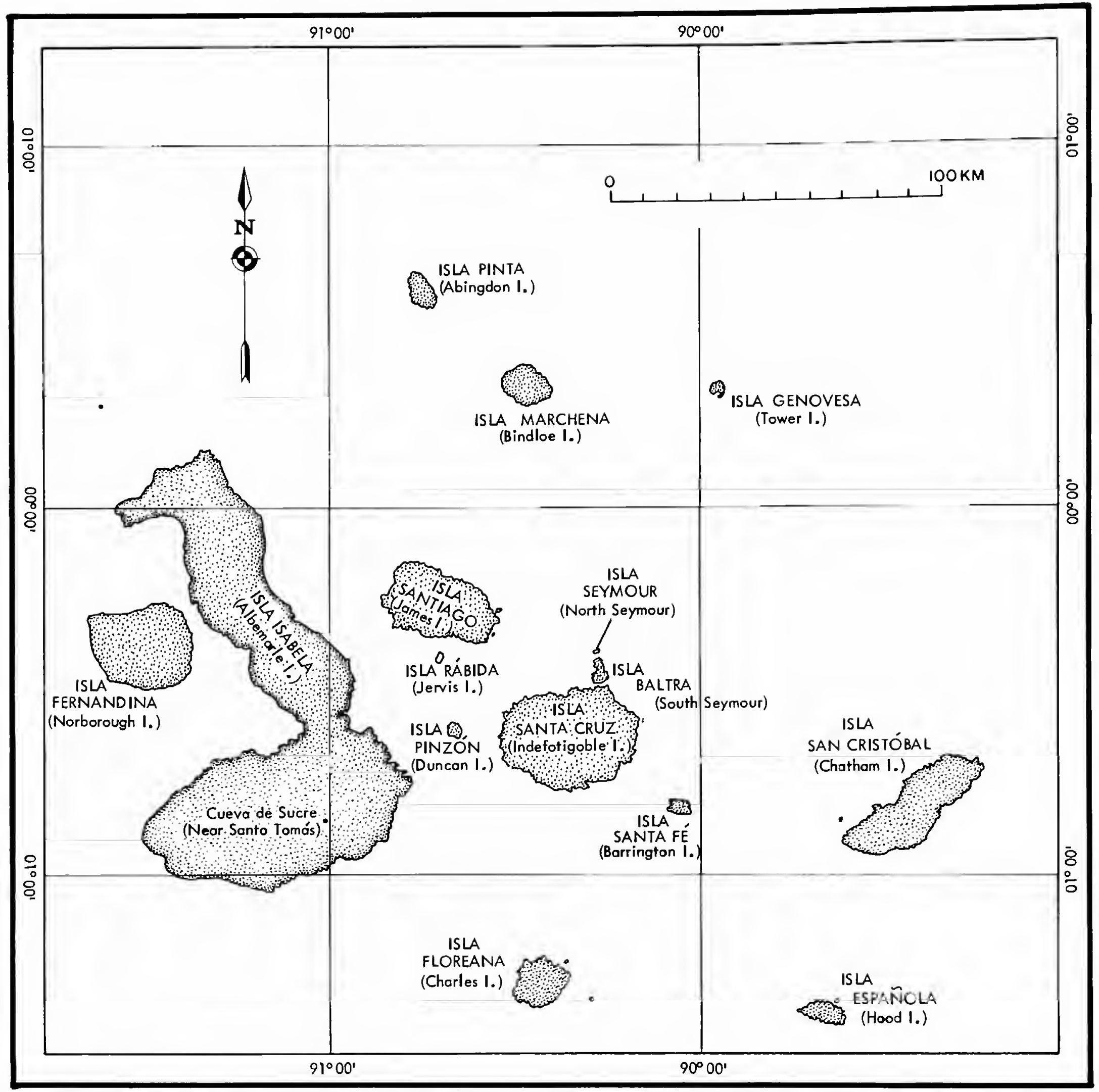

Figure 1.-The Galápagos Archipelago, showing major islands only. (See "Materials and Methods" and Figure 2 for details of localities on Isla Santa Cruz.)

172978 (Venezuela); O. xanthaeolus, USNM 277566, 302987, 302991 (Perú); O. bauri, USNM 392257 (Isla Sante Fé, Galápagos); Nesoryzomys indefessus, USNM 115832, 115834, 259312 (Islas Santa Cruz and Baltra, Galápagos); N. narboroughi, USNM 259552 (Isla Fernandina, Galápa- gos); N. swarthi, CAS 2561 (Isla Santiago); $M e-$ galomys "pilorides" (= desmarestii $), \mathrm{BM}(\mathrm{NH})$ 1850.11.30.6 (Martinique); $M$. desmarestii, $\mathrm{BM}(\mathrm{NH})$ 1855.12.24.201 (Martinique), Leiden Museum "a" (Martinique); M. luciae, BM(NH) 1853.12.16.2 (St. Lucia); Macruroryzomys hammondi, 


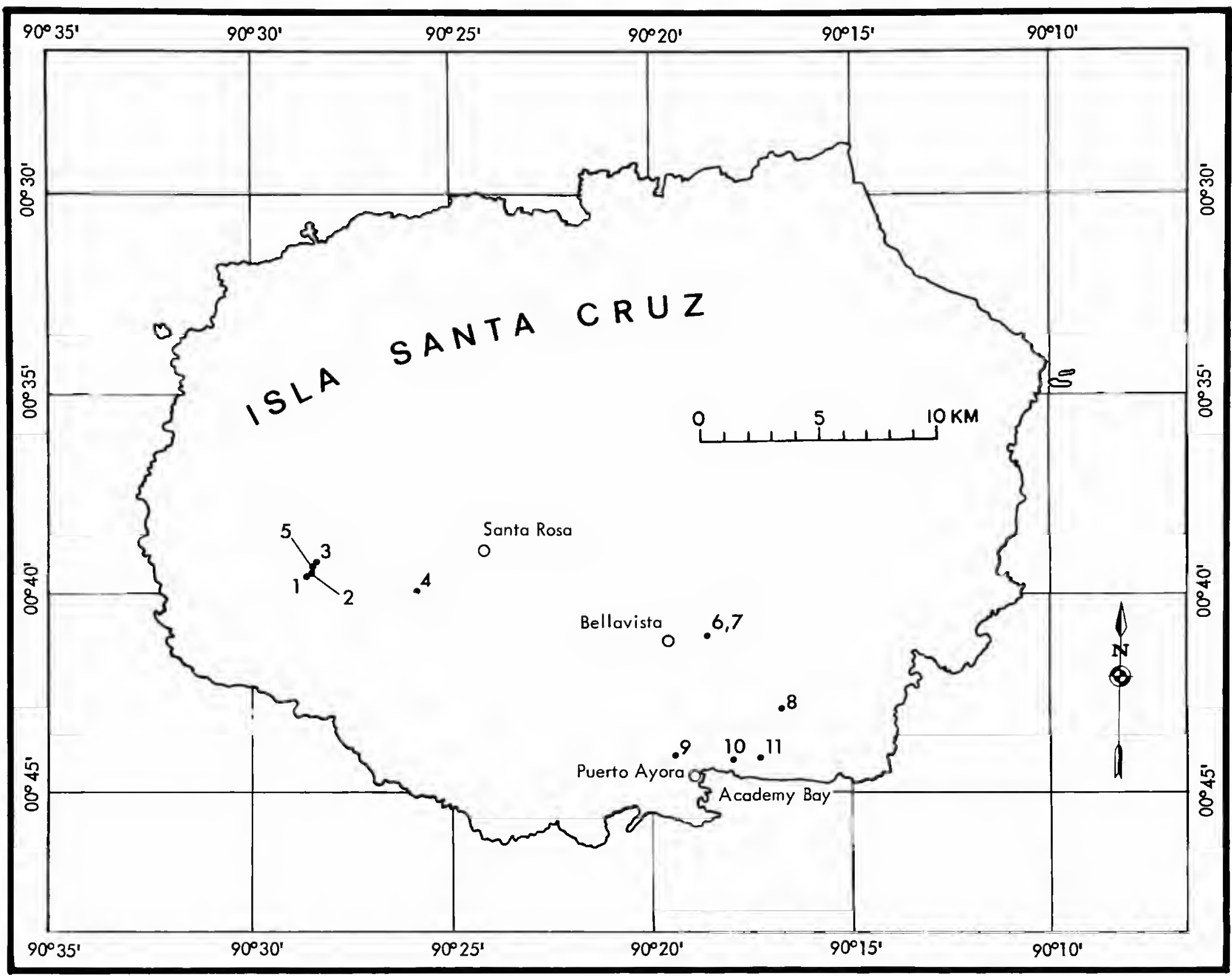

Figure 2.-Localities of Megaoryzomys on Isla Santa Cruz: 1, cave no. 1 (= cave in Naranja Zone); 2, cave no. 2 (contains no remains of Megaoryzomys); 3, cave no. 3; 4, cave no. 4 (= cave north of El Chato); 5, cave no. 5 (= cave north of Reserve in Naranja Zone); 6, cave near Bellavista; 7, cave near Bellavista (not definitely the same cave as no. 6); 8, cave in Cascajo Mountains (type-locality); 9, Cueva de Kubler; 10, Cueva de Iguana; 11, André's Cave. (See "Materials and Methods" for further information on these sites.)

$\mathrm{BM}(\mathrm{NH})$ 1913.10.24.55 (Ecuador); Nectomys saturatus, BM(NH) 1897.11.7.40 (Ecuador); Tylomys species, USNM 298732, 309223, 323971 (Panamá); T. mirae, USNM 113318 (Ecuador); Scapteromys tumidus, USNM 392888 (Uruguay); S. chacoensis, USNM 12170/8379 (Argentina); Kunsia tomentosus, USNM 364760 (Bolivia); Phyllotis boliviensis, USNM 121148, 391802 (Bolivia, Chile). In addition, the following archeological material of Megalomys was examined: $M$. desmarestii, USNM
293780A,B,C (dentaries; Martinique); M. luciae, LSU field No. 76ch, 76ci, 76cj (dentaries; St. Lucia); UF/FSM field No. 61a-39 (maxilla; St. Lucia).

Measurements.-Statistics (mean, range, sample size) presented here are based on all adults of Megaoryzomys curioi examined in this study, exclusive of the holotype. Standard deviation is given for samples of 10 or more specimens. All specimens are from Isla Santa Cruz and are housed 
either in the NMNH or the CDRS. Terminology for the first seven measurements follows Thomas (1905). All of the following measurements were made with dial calipers and were rounded to the nearest $0.1 \mathrm{~mm}$.

greatest length between uprights 55.6, 1

condylobasal length $54.45,53.3-55.6,2$

condylobasilar length $50.50,49.3-51.7,2$

basal length $50.25,48.8-51.7,2$

basilar length $46.25,45.1-47.4,2$

palatal length $30.30,28.6-32.0,3$

patatilar length $25.33,24.6-26.5,3$

length of diastema 16.05, 15.1-17.3, 4

length of foramina incisivi $10.84,9.6-11.7,5$

length of palate $10.35,9.9-10.6,4$

zygomatic width $34.3+, 33.8+-34.8+, 2$

minimum width of braincase just posterior to zygomatic arch $19.03,18.7-19.2,3$

minimum interorbital width 8.22, 7.3-8.6, 4

width of zygomatic plate of maxilla 8.06, 6.9-8.7, 6

greatest width of rostrum $11.67,11.0-12.3,3$

depth of rostrum at anterior end of foramina incisivi 11.93, $11.8-12.1,3$

least width of palate (between alveoli of $\mathrm{M}^{1} \mathrm{~s}$ ) 4.20, 3.5-5.1, 5

length of interparietal at midline $4.40,4.4,2$

width of interparietal $13.60,12.8-14.4,2$

width through occipital condyles $12.00,11.8-12.2,2$

alveolar length of upper molars $11.48 \pm 0.44,10.9-12.3,13$

crown length of upper molars $10.86,10.0-11.5,5$

length $M^{1} 4.92 \pm 0.28,4.5-5.6,20$

width $\mathrm{M}^{1} 3.56 \pm 0.17,3.3-3.9,20$

length $\mathrm{M}^{2} 3.31 \pm 0.17,3.0-3.6,14$

width $\mathrm{M}^{2} 3.40 \pm 0.17,3.1-3.7,14$

length $\mathrm{M}^{3} 2.42,2.3-2.5,5$

width $\mathrm{M}^{3} 2.80,2.7-2.9,5$

length of dentary with incisor $38.10,36.5-40.8,7$

length of dentary without incisor $34.64,33.4-35.5,5$

alveolar length of lower molars $12.59 \pm 0.56,11.7-13.6,22$

crown length of lower molars 12.06, 11.5-12.7, 9

length $M_{1} 5.17 \pm 0.18,4.8-5.5,15$

width $\mathrm{M}_{1} 3.28 \pm 0.12,3.1-3.5,14$

length $\mathrm{M}_{2} 3.54 \pm 0.15,3.2-3.8,16$

width $\mathrm{M}_{2} 3.29 \pm 0.14,3.0-3.5,15$

length $\mathrm{M}_{3} 3.35 \pm 0.23,2.9-3.7,11$

width $\mathrm{M}_{3} 2.74 \pm 0.12,2.6-2.9,11$

\section{Description and Comparisons}

Megaoryzomys curioi was described from a left maxilla (lacking $\mathrm{M}^{3}$ ) and fragments of a humerus and scapula that were found in 1962-1963 by Dr.
E. Curio in a cave (= lava tube) of unknown name or exact locality in the Cascajo Mountain area of Isla Santa Cruz (Niethammer, 1964:596, 600). Cascajo Mountain is approximately $7-8 \mathrm{~km}$ north of Academy Bay, although Abs et al. (1965:52) stated that the cave was approximately $15 \mathrm{~km}$ northeast of Academy Bay. The three original specimens of Megaoryzomys were found with the bones of four other species of rodents: Nesoryzomys indefessus, $N$. darwini, and two introduced species, Rattus rattus and Mus musculus. Unlike the remains of Megaoryzomys, those of the other four rodents were in the form of owl pellets, probably from the Galápagos barn owl (Tyto punctatissima). The bones of Megaoryzomys, although not mineralized, gave Niethammer the impression of being older than those of the other rodents from the same locality.

The three cotypes of Megaoryzomys curios are deposited in the British Museum (Natural History), where they are housed in the Modern Mammal Section and bear the number $\mathrm{BM}(\mathrm{NH})$ 67.1649. As Niethammer (1964:598) presented no evidence to indicate that the three specimens designated as "type" represent a single individual, the maxillary fragment should be regarded as the holotype, and the scapula and humerus as paratypes. Contrary to the assertions of Lenglet and Coppois (1979:633), neither their specimens nor any others could possibly be types of their new genus, for which the species curior, based on Niethammer's specimens, is of course the type. Our measurements of the holotype, a maxilla, of Megaoryzomys curioi (alveolar length of upper molars $11.4 \mathrm{~mm}$, length $\mathrm{M}^{1} 5.1 \mathrm{~mm}$, width $\mathrm{M}^{1} 3.5$ mm, length $\mathrm{M}^{2} 3.3 \mathrm{~mm}$, width $\mathrm{M}^{2} 3.4 \mathrm{~mm}$ ) are well within the range of variation of other specimens examined in this study (see "Measurements"). In addition, we could find no qualitative differences between our series of specimens and the holotype. Thus we are confident that our material represents the species described by Niethammer (1964).

Niethammer $(1964: 598,599)$ placed his species in the West Indian genus Megalomys based on the following characters: (1) the similar enamel pat- 

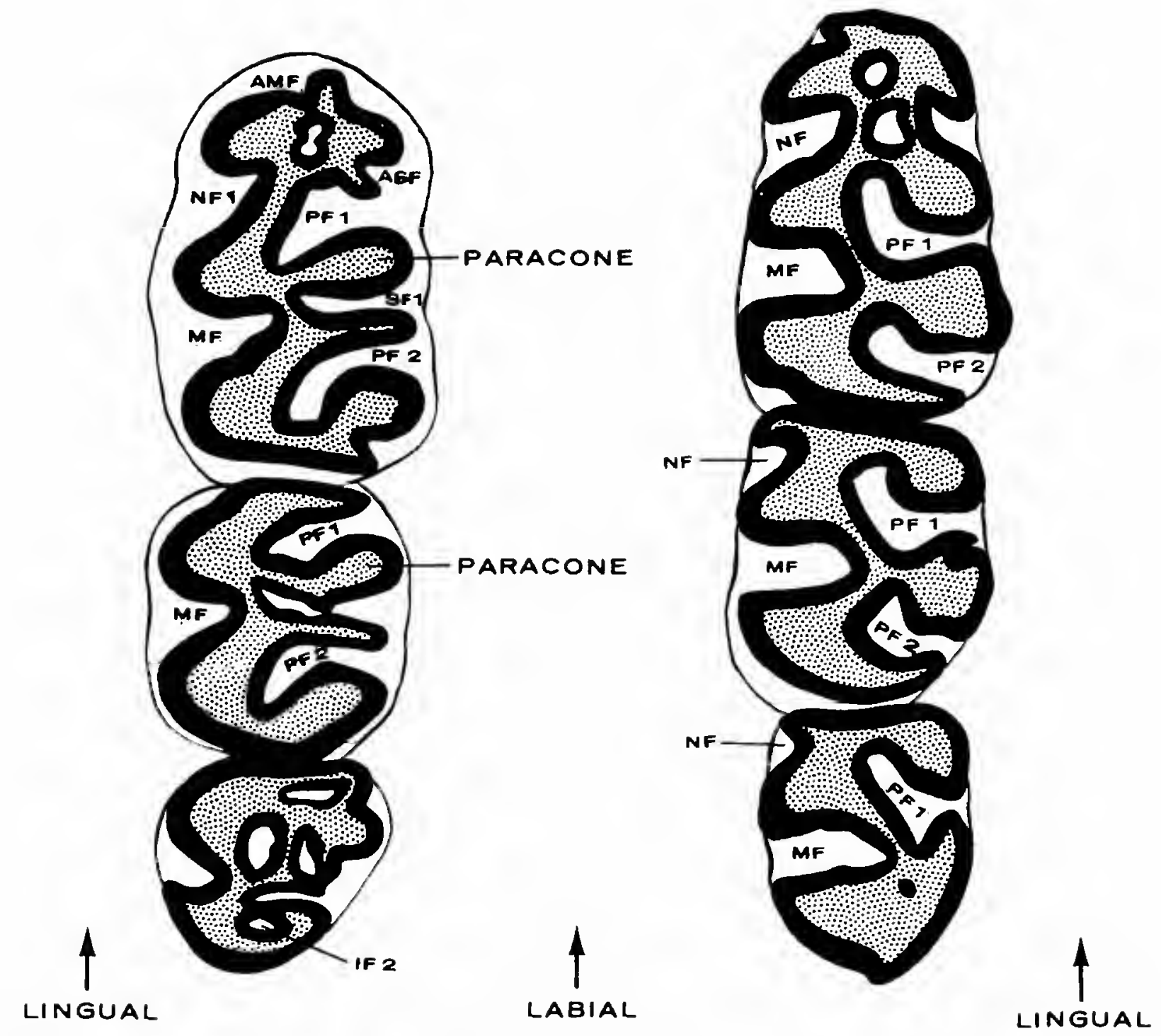

\section{A UPPER LEFT MOLARS}

B LOWER LEFT MOLARS

FIGURE 3.-Nomenclature of enamel patterns of molars of Megaoryzomys, including only those names used in the text: A, upper left molars (USNM 284317, reversed); в, lower left molars (USNM 284290, reversed). (Terminology follows Hershkovitz (1967); AMF = anterior median fold; $\mathrm{ASF}=$ anterior secondary fold; $\mathrm{IF} 2=2 \mathrm{nd}$ internal fold; $\mathrm{MF}=$ major fold; $\mathrm{NF}=$ minor fold; $\mathrm{PF} 1=1$ st primary fold; $\mathrm{PF} 2=2 \mathrm{nd}$ primary fold; $\mathrm{SF} 1=1$ st secondary fold.)

terns of its upper molars, (2) the similar pattern of the roots of the upper molars, (3) foramina incisivi that terminate anterior to the molars, (4) its large size. We will now re-analyze these characters, demonstrating that they do not suffice to place curioi in the oryzomyine genus Megalomys.

1. The similar enamel pattern of its upper molars. Niethammer (1964) said that the positions of enamel folds 1 and 3-8 of $\mathrm{M}^{1-2}$ (as shown in figure 4 of Niethammer) in Megaoryzomys are similar to those in Megalomys desmarestii of Martinique, Lesser Antilles. Niethammer's enamel folds 1-8 correspond sequentially to the following terms used herein (Figure 3): $\mathrm{M}^{1}-$ PF.1, SF.1,
PF.2, NF, MF; M $^{2}$-PF.1, PF.2, MF. The positions of enamel folds in Megaoryzomys generally resemble those in Megalomys (Figure 4), but $\mathrm{Me}$ gaoryzomys differs from Megalomys and resembles the Neotropical cricetine Thomasomys in lacking IF.2 on $\mathrm{M}^{1-2}$ and in the presence of $\mathrm{AMF}$ and ASF. Thomasomys differs from both Megaoryzomys and Megalomys in its more nearly circular paracone on $\mathrm{M}^{1-2}$. We agree with Niethammer that the "labial grooves" (major and minor folds) are deeper in Megaoryzomys than in specimens of Megalomys at a similar stage of wear.

Niethammer (1964) did not have any lower molars of Megaoryzomys. Our examination of 


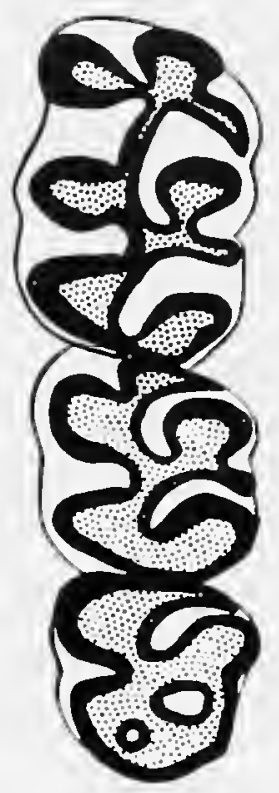

A

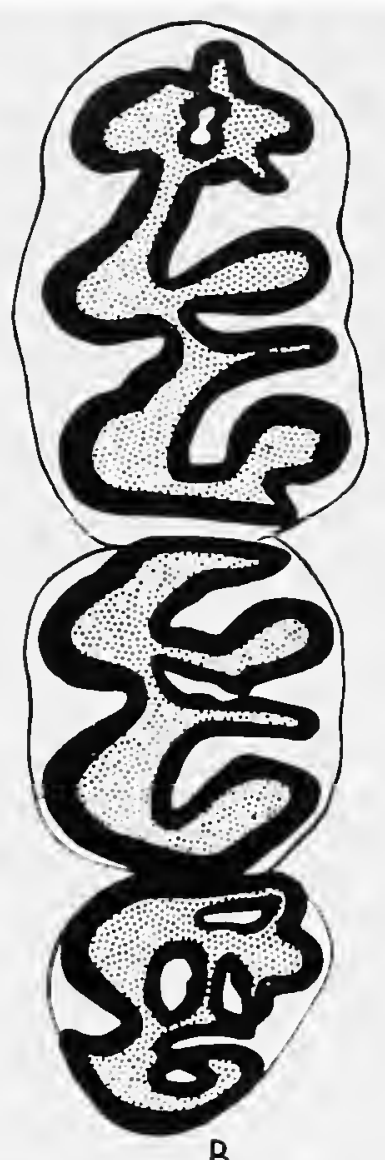

B

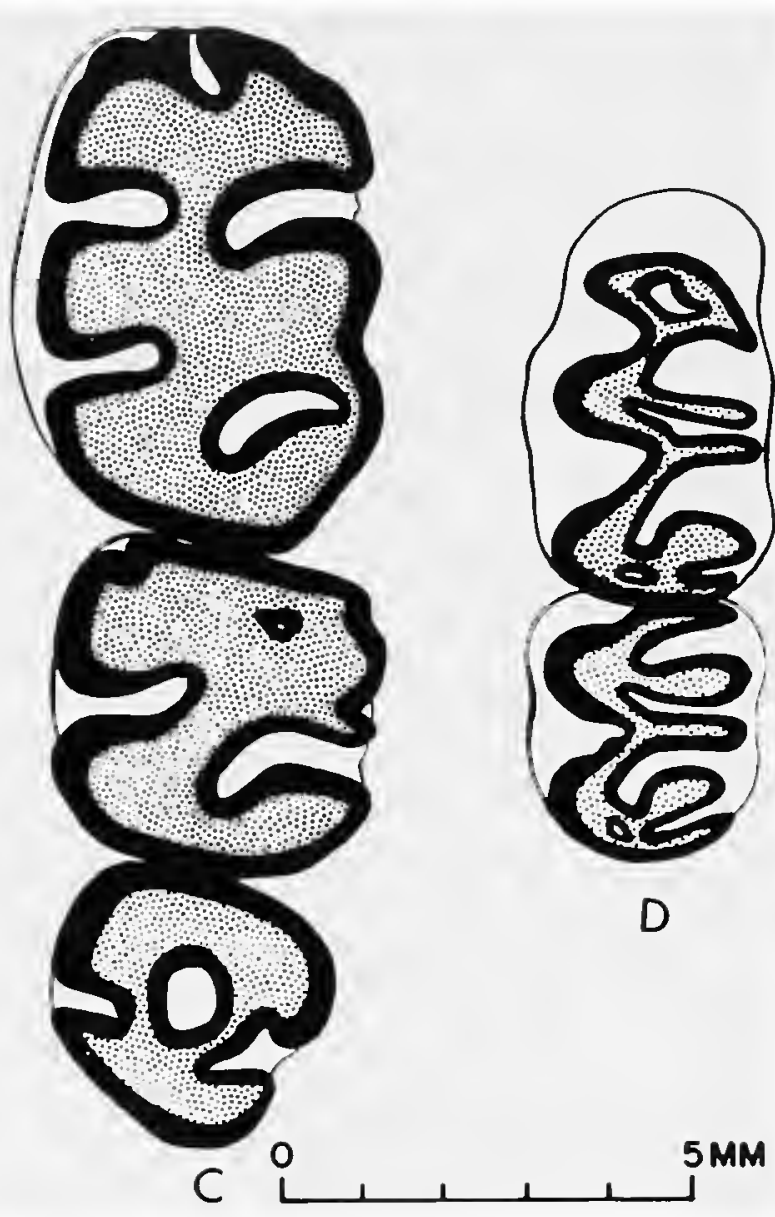

C
$5 M M$

Figure 4.-Comparison of enamel patterns in left upper molars: A, Thomasomys aureus, USNM 194827; B, Megaoryzomys curnol, USNM 284317 (reversed); c, Megaoryzomys curioi, USNM 284318; D, Megalomys luciae, UF/FSM field no. 61a-39.

enamel patterns of the lower molars of Megaoryzomys (Figure 5) reveals more similarities to those of Thomasomys than to Megalomys. All primary, minor, and major folds in $\mathrm{M}_{1-3}$ are deeper and wider in Megaoryzomys and Thomasomys than in Megalomys at a similar stage of wear. The MF of $\mathrm{M}_{2}$ is located more anteriorly in Megalomys than in the other two genera. Thomasomys differs from both in its prominent AMF.

2. The similar pattern of the roots of the upper molars. Because we have no specimens of Megalomys in which the alveoli of the upper molars are exposed, we cannot comment in detail on the status of this character, which is additionally obscured by Niethammer's (1964) failure to identify the taxa represented by alveolar palterns $\mathrm{A}$, $\mathrm{B}$, and $\mathrm{C}$ in his figure 3 . We have, however, found the alveolar pattern of the upper molars in Megaoryzomys (seven specimens) to be identical to those in the only specimens of Thomasomys available with exposed alveoli-one specimen each of $T$. cinereus and $T$. ischyrus.
3. Foramina incisivi that terminate anterior to the molars. In Megaoryzomys, Thomasomys, and Rhipidomys, the posterior border of the foramina incisivi is even with, or only very slightly anterior to, the anterior border of $\mathrm{M}^{1}$, whereas in Megalomys the foramina incisivi terminate well anterior to the molars (Figures 6 and 9). Thus Niethammer's character actually supports a thomasomyine allocation of Megaoryzomys, which differs greatly from Megalomys in this regard.

4. Its large size. Large size is of little value in assigning a cricetine rodent to genus or tribe. Among the mainland cricetines that are comparable in size to true Megalomys are Tylomys mirae (Peromyscini), Nectomys squamipes (Oryzomyini), Kunsia tomentosus (Scapteromyini), and Holochilus magnus (Sigmodontini), each of which is, like Megalomys, very different from Megaoryzomys. In addition, gigantism is a common occurrence in insular rodents, and thus the nearest mainland relative of any well-differentiated insular rodent 

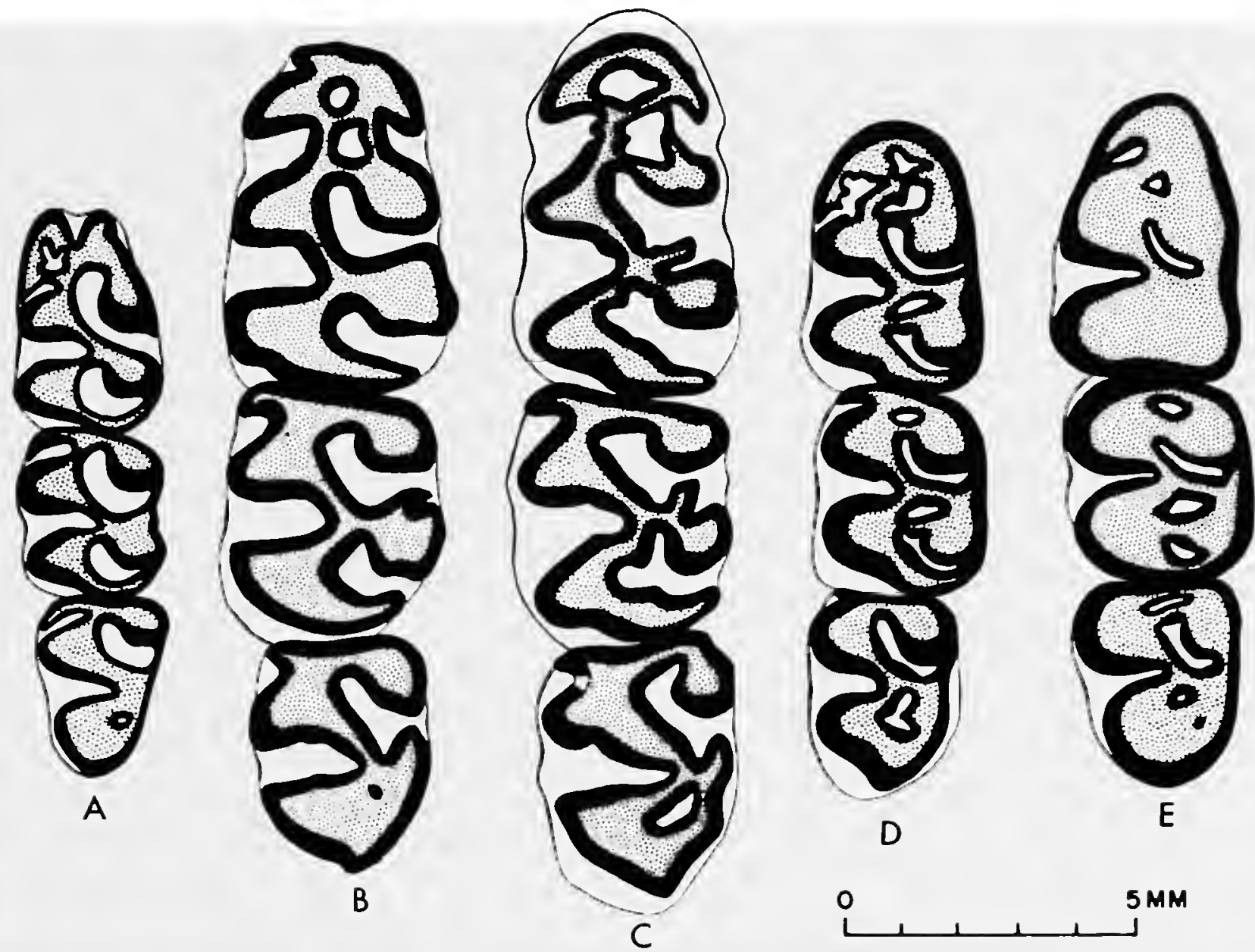

Figure 5.-Comparison of enamel patterns of left lower molars: A, Thomasomys aureus, USNM 194827; B, Megaoryzomys curioi, USNM 284290 (reversed); c, Megaoryzomys curioi, USNM 284299 (reversed); D, Megalomys luciae, LSU field no. 76ch (reversed); E, Megalomys desmarestii, USNM 293780c.

may well be smaller than its insular derivative. Gigantism in muroid rodents on islands has been abundantly documented, for example, in living species by Berry $(1964,1981)$ and Foster (1964), and in the Quaternary of the East Indies (Musser, 1981) and West Indies (Ray, 1962), the Canary Islands (Crusafont-Pairo and Petter, 1964), and the California Channel Islands (Gill, 1980; Walker, 1980). Certain Quaternary caviomorph rodents of the West Indies (systematically listed in Varona, 1974) also attained very large size, as did dormice in the Mediterranean (Petronio, 1970).

Thus the characters used by Niethammer (1964) to refer curioi to the genus Megalomys are invalid. Except for Lenglet and Coppois (1979), no author since Niethammer (1964) has seriously questioned its original assignment to the oryzomyine genus Megalomys. Abs et al. (1965), Orr
(1966), Peterson (1966), Hooijer (1967), Hershkovitz (1970, 1972), Müller (1973), Hutterer and Hirsch (1979), and Patton and Hafner (in press) mention the existence of "Megalomys" in Galápagos without systematic comment. To evaluate its affinities further, we compared Megaoryzomys to all genera and most species of Neotropical Cricetinae represented in the collections of the $\mathrm{Di}$ vision of Mammals, NMNH, supplemented by additional forms from the other museums. The majority of these species could be eliminated readily as near relatives of Megaoryzomys because of their relatively long palate, relatively small teeth, and differently shaped interorbital region. Table 1 includes only those species whose size or morphology are such that they deserved more serious consideration.

Megaoryzomys is not closely related to Megalomys; in addition to the characters in Table 1, Megalomys 
Table 1.-Comparison of cranial characteristics of Megaoryzomys curioi and certain other species of cricetine rodents

\begin{tabular}{|c|c|c|c|c|c|c|}
\hline Species & $\begin{array}{l}\text { Depression } \\
\text { along median } \\
\text { suture of } \\
\text { frontals } \\
\end{array}$ & $\begin{array}{c}\text { Shape of } \\
\text { interorbital } \\
\text { region } \\
\text { (Figures } 7,9 \text { ) } \\
\end{array}$ & $\begin{array}{c}\text { Length and } \\
\text { width of palate } \\
\text { relative to length } \\
\text { of tooth row } \\
\text { (Figures } 6,9 \text { ) } \\
\end{array}$ & $\begin{array}{c}\text { Size of } \\
\text { teeth relative } \\
\text { to size of } \\
\text { entire skull } \\
\text { (Figures } 6,8,9 \text { ) }\end{array}$ & $\begin{array}{l}\text { Dorsolateral } \\
\text { ridge of } \\
\text { braincase }\end{array}$ & $\begin{array}{c}\text { Palatal } \\
\text { foramina } \\
\text { (Figures 6,9) }\end{array}$ \\
\hline $\begin{array}{l}\text { Megaoryzomys } \\
\text { curioz }\end{array}$ & deep & $\begin{array}{l}\text { strongly } \\
\text { constricted, } \\
\text { with abrupt } \\
\text { lateral } \\
\text { expansion of } \\
\text { squamosals }\end{array}$ & short, narrow & large & $\begin{array}{l}\text { well developed, } \\
\text { but not sharp or } \\
\text { laterally } \\
\text { expanded }\end{array}$ & large; numerous \\
\hline Thomasomys aureus & $\begin{array}{l}\text { shallow } \\
\text { to deep }\end{array}$ & as in curioz & short, narrow & large & $\begin{array}{l}\text { as in } \\
M . \text { curtoi, but } \\
\text { slightly less } \\
\text { developed in } \\
\text { parietal region }\end{array}$ & small; few \\
\hline T. praelor & deep & $\begin{array}{l}\text { as in } \\
\quad M . \text { curioi }\end{array}$ & $\begin{array}{l}\text { short, narrow } \\
\text { to intermediate } \\
\text { in width }\end{array}$ & large & $\begin{array}{l}\text { as in } \\
\quad M . \text { curior }\end{array}$ & $\begin{array}{l}\text { small to } \\
\text { medium sized; } \\
\text { few }\end{array}$ \\
\hline$T$. princeps & intermediate & $\begin{array}{l}\text { as in } \\
\quad M . \text { curnol }\end{array}$ & short, narrow & large & $\begin{array}{l}\text { as in } \\
\quad T . \text { aureus }\end{array}$ & $\begin{array}{l}\text { small to } \\
\text { medium sized; } \\
\text { few }\end{array}$ \\
\hline T. pyrrhonolus & shallow & $\begin{array}{l}\text { as in } \\
\quad M . \text { curioi }\end{array}$ & short, narrow & large & $\begin{array}{l}\text { as in } \\
\quad T \text {. aureus }\end{array}$ & $\begin{array}{l}\text { small to } \\
\text { medium sized; } \\
\text { few }\end{array}$ \\
\hline T. cinereiventer & shallow & $\begin{array}{l}\text { wider than } \\
\text { in } M . \text { currot }\end{array}$ & short, wide & large & very small & small; few \\
\hline T. cinereus & shallow & $\begin{array}{l}\text { as in } \\
M \text {. curroi, } \\
\text { but more } \\
\text { bulbous }\end{array}$ & short, wide & intermediate & very small & $\begin{array}{l}\text { extremely small; } \\
\text { very few }\end{array}$ \\
\hline T. hylophilus & shallow & $\begin{array}{l}\text { as in } \\
\quad M . \text { curnoi }\end{array}$ & short, wide & intermediate & $\begin{array}{l}\text { between } \\
T . \text { aureus and } \\
T . \text { cinereus }\end{array}$ & small; numerous \\
\hline $\begin{array}{l}T . \text { ischyrus and } \\
T . \text { kalınowskn? }\end{array}$ & shallow & $\begin{array}{l}\text { wider and } \\
\text { more bulbous } \\
\text { than in } \\
\text { M. curoi }\end{array}$ & short, wide & intermediate & very small & small; few \\
\hline T. rhoadsl & shallow & $\begin{array}{l}\text { wider than } \\
\text { in } \\
\text { M. cunoi }\end{array}$ & short, wide & intermediate & very small & small; few \\
\hline $\begin{array}{l}\text { Rhipldomys } \\
\text { leucodactylus }\end{array}$ & shallow & $\begin{array}{l}\text { wider than in } \\
M . \text { curioi, } \\
\text { especially in } \\
\text { posterior half }\end{array}$ & short, wide & intermediate & $\begin{array}{l}\text { sharper with } \\
\text { more lateral } \\
\text { flare in } \\
\text { interorbital } \\
\text { region than in } \\
\text { Thomasomys or } \\
\text { M. cunvi }\end{array}$ & small; few \\
\hline R. caucensis & shallow & $\begin{array}{l}\text { wider than } \\
\text { in } \\
\text { M. curzot }\end{array}$ & short, wide & intermediate & $\begin{array}{l}\text { as in } \\
\quad R \text {. leucodactylus }\end{array}$ & $\begin{array}{l}\text { absent or } \\
\text { small and } \\
\text { few }\end{array}$ \\
\hline R. goodfellowi & shallow & $\begin{array}{l}\text { wider than } \\
\text { in } \\
M \text {. curioi }\end{array}$ & short, wide & intermediate & $\begin{array}{l}\text { as in } \\
\quad R . \text { leucodaclylus }\end{array}$ & small; few \\
\hline R. venezuelae & shallow & $\begin{array}{l}\text { as in } \\
\quad M . \text { curioi }\end{array}$ & $\begin{array}{l}\text { short, wide or } \\
\text { narrow }\end{array}$ & intermediate & $\begin{array}{l}\text { as in } \\
\quad M . \text { curnoi }\end{array}$ & $\begin{array}{l}\text { small to } \\
\text { medium sized; } \\
\text { rather } \\
\text { numerous }\end{array}$ \\
\hline$R$. venuslus & shallow & $\begin{array}{l}\text { wider than } \\
\text { in } \\
M . \text { curioi, } \\
\text { with more } \\
\text { gradual } \\
\text { posterior } \\
\text { expansion }\end{array}$ & short, wide & intermediate & $\begin{array}{l}\text { as in } \\
\quad R \text {. leucodactylus }\end{array}$ & $\begin{array}{l}\text { absent or } \\
\text { very small } \\
\text { and few }\end{array}$ \\
\hline $\begin{array}{l}\text { Oryzamys } \\
\text { palustris }\end{array}$ & shallow & $\begin{array}{l}\text { wider than in } \\
M . \text { curioi, } \\
\text { with gradual } \\
\text { lateral expansion } \\
\text { of frontals }\end{array}$ & $\begin{array}{l}\text { long, inter- } \\
\text { mediate in } \\
\text { width }\end{array}$ & intermediate & $\begin{array}{l}\text { very large and sharp; } \\
\text { oriented diagonally } \\
\text { or laterally }\end{array}$ & $\begin{array}{l}\text { at least two } \\
\text { large foramina, } \\
\text { with varying } \\
\text { number of } \\
\text { smaller } \\
\text { foramina }\end{array}$ \\
\hline
\end{tabular}


Table 1.-Continued

\begin{tabular}{|c|c|c|c|c|c|c|}
\hline Species & $\begin{array}{c}\text { Depression } \\
\text { along median } \\
\text { suture of } \\
\text { frontals } \\
\end{array}$ & $\begin{array}{c}\text { Shape of } \\
\text { interorbital } \\
\text { region } \\
\text { (Figures } 7,9 \text { ) }\end{array}$ & $\begin{array}{l}\text { Length and } \\
\text { width of palate } \\
\text { relative to length } \\
\text { of tooth row } \\
\text { (Figures } 6,9 \text { ) } \\
\end{array}$ & $\begin{array}{c}\text { Size of } \\
\text { teeth relative } \\
\text { to size of } \\
\text { entire skull } \\
\text { (Figures } 6,8,9 \text { ) }\end{array}$ & $\begin{array}{c}\text { Dorsolatcral } \\
\text { ridge of } \\
\text { braincase }\end{array}$ & $\begin{array}{c}\text { Palatal } \\
\text { foramina } \\
\text { (Figures 6.9) }\end{array}$ \\
\hline O. albigularis & $\begin{array}{c}\text { shallow or } \\
\text { absent }\end{array}$ & $\begin{array}{l}\text { as in } \\
\quad M . \text { curooi }\end{array}$ & $\begin{array}{l}\text { as in } \\
\quad \text { O. palustris }\end{array}$ & $\begin{array}{l}\text { large to } \\
\text { intermediate } \\
\text { in size }\end{array}$ & $\begin{array}{l}\text { not well developed } \\
\text { in interorbital } \\
\text { region }\end{array}$ & $\begin{array}{l}\text { as in } \\
\text { O. palustris }\end{array}$ \\
\hline O. xanthaeolus & shallow & $\begin{array}{l}\text { as in } \\
\quad 0 . \text { palustris }\end{array}$ & $\begin{array}{l}\text { as in } \\
\quad O . \text { palustrus }\end{array}$ & intermediate & $\begin{array}{l}\text { as in } \\
\quad O . \text { palusiris }\end{array}$ & $\begin{array}{l}\text { as in } \\
\text { O. palustris }\end{array}$ \\
\hline O. baurl & shallow & $\begin{array}{l}\text { as in } \\
\quad 0 . \text { palustris }\end{array}$ & $\begin{array}{l}\text { short, } \\
\text { int ermediate } \\
\text { in width }\end{array}$ & intermediate & $\begin{array}{l}\text { as in } \\
\quad \text { O. palustrz.s }\end{array}$ & large; numerous \\
\hline $\begin{array}{l}\text { Nesoryzomys } \\
\text { indefessus and } \\
N . \text { narboroughi }\end{array}$ & shallow & $\begin{array}{l}\text { as in } \\
\quad M . \text { curnor }\end{array}$ & $\begin{array}{l}\text { long, } \\
\text { intermediate } \\
\text { in width }\end{array}$ & intermcdiate & $\begin{array}{l}\text { Icss distinct } \\
\text { than in } M \text {. curiol, } \\
\text { especially in } \\
\text { posterior half }\end{array}$ & largc; numerous \\
\hline $\begin{array}{l}\text { Megalomys } \\
\text { "pilorides" } \\
(=M . \text { desmarestii) }\end{array}$ & absent & $\begin{array}{l}\text { basically as } \\
\text { in } M \text {. curooi, } \\
\text { but wider }\end{array}$ & $\begin{array}{l}\text { long, } \\
\text { intermediate } \\
\text { in width }\end{array}$ & intermediate & $\begin{array}{l}\text { extremely large; } \\
\text { oriented mainly } \\
\text { dorsally; not } \\
\text { sharp }\end{array}$ & large; numcrous \\
\hline M. desmarestii & absent & $\begin{array}{l}\text { wider than in } \\
M . \text { curioi, with } \\
\text { more gradual } \\
\text { posterior } \\
\text { expansion of } \\
\text { frontals }\end{array}$ & $\begin{array}{l}\text { as in } \\
\quad \text { Megalomys "pilondes" }\end{array}$ & intermediate & $\begin{array}{l}\text { large; diagonally } \\
\text { oriented; sharp }\end{array}$ & largc; numerous \\
\hline M. Luciae & absent & $\begin{array}{l}\text { as in } \\
\text { Megalomys } \\
\text { desmarestii }\end{array}$ & $\begin{array}{l}\text { as in } \\
\quad \text { Megalomys "pulondes" }\end{array}$ & small & $\begin{array}{l}\text { very large; } \\
\text { oriented mainly } \\
\text { diagonally; sharp }\end{array}$ & large; numerous \\
\hline $\begin{array}{l}\text { Macruronyzomys } \\
\text { hammondl }\end{array}$ & shallow & $\begin{array}{l}\text { as in } \\
\text { Megalomys } \\
\text { desmarestii }\end{array}$ & $\begin{array}{l}\text { as in } \\
\quad \text { Megalomys "pilorides" }\end{array}$ & small & $\begin{array}{l}\text { medium sized; } \\
\text { diagonally } \\
\text { oriented; sharp }\end{array}$ & large; numerous \\
\hline Nectomys saluratus & absent & $\begin{array}{l}\text { as in } \\
\text { Megalomys } \\
\text { desmarestii }\end{array}$ & $\begin{array}{l}\text { intermediate } \\
\text { in length } \\
\text { and width }\end{array}$ & intermediate & $\begin{array}{l}\text { medium sized; } \\
\text { oriented diagonally: } \\
\text { sharp }\end{array}$ & large; numerous \\
\hline $\begin{array}{l}\text { Tylomys species } \\
\text { and } \\
\text { T. mirae }\end{array}$ & very shallow & $\begin{array}{l}\text { wider than in } \\
M . \text { curiol }\end{array}$ & $\begin{array}{l}\text { short, } \\
\text { intermediate } \\
\text { in width }\end{array}$ & intermediate & $\begin{array}{l}\text { larger and more } \\
\text { distinct than } \\
\text { in } M . \text { cunzoi; } \\
\text { laterally oriented; } \\
\text { sharp }\end{array}$ & very small; few \\
\hline $\begin{array}{l}\text { Scapleromys } \\
\text { tumidus }\end{array}$ & absent & $\begin{array}{l}\text { as in } \\
\text { M. curlol }\end{array}$ & $\begin{array}{l}\text { intermediate } \\
\text { in length, } \\
\text { narrow }\end{array}$ & intermediate & extremely small & very small; few \\
\hline S. chacoensis & absent & $\begin{array}{l}\text { as in } \\
\quad M . \text { curioz }\end{array}$ & $\begin{array}{l}\text { as in } \\
\text { S. tumidus }\end{array}$ & intermediate & extremely small & very small; few \\
\hline Kunsia tomentosus & absent & $\begin{array}{l}\text { as in } \\
\quad M . \text { curioz }\end{array}$ & short, narrow & intermediate & $\begin{array}{l}\text { less distinct } \\
\text { than in } M \text {. curtoi } \\
\text { in interorbital } \\
\text { region only }\end{array}$ & small; few \\
\hline $\begin{array}{l}\text { Phyllotis } \\
\text { boliviensis }\end{array}$ & shallow & $\begin{array}{l}\text { as in } \\
\quad M . \text { curiol }\end{array}$ & short, wide & intermediate & $\begin{array}{l}\text { less distinct } \\
\text { overall than } \\
\text { in } M . \text { curtol }\end{array}$ & $\begin{array}{l}\text { small to } \\
\quad \text { large; few }\end{array}$ \\
\hline
\end{tabular}

is different from Megaoryzomys in that its zygomatic process of the squamosal joins the braincase at a more acute angle, its occipital condyles and foramen magnum are much smaller, and the masseteric crests on the dentary terminate more anteriorly (see Figure 10). Among cricetine rodents, Megaoryzomys differs in at least several important ways (Table 1) from other large oryzo- myines (Marcruroryzomys, Nectomys), as well as Tylomys, Scapteromys, Kunsia, and Phyllotis. The endemic oryzomyine rodents of Galápagos (Oryzomys galapagoensis, O. bauri, Nesoryzomys indefessus, N. narboroughi, $N$. fernandinae, $N$. darwini, and $N$. swarthi) also are very different from Megaoryzomys in several characters (Table 1) and may be ruled out as close relatives of the latter. 

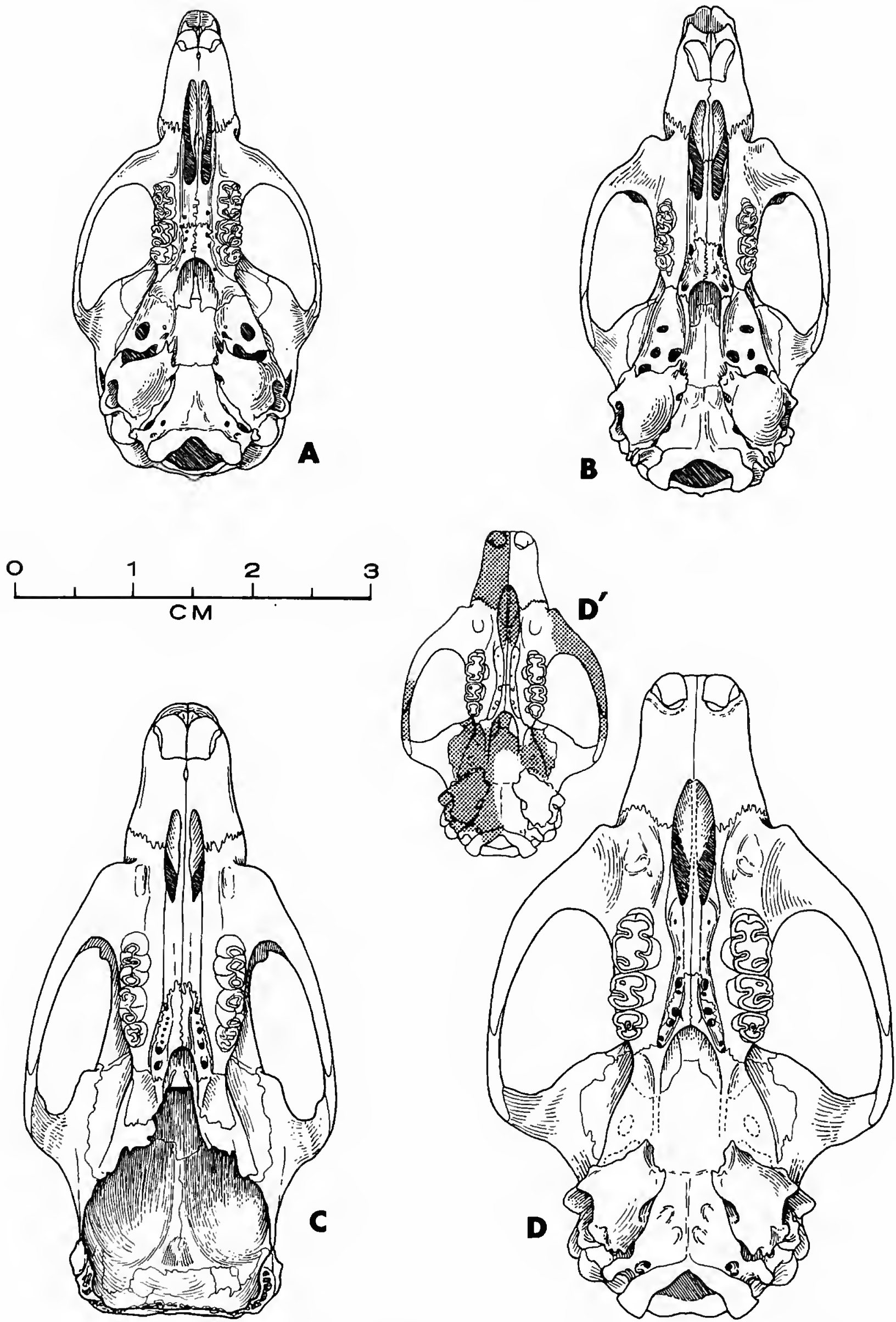

FigURE 6._Skulls in ventral aspect: A, Thomasomys aureus, female, USNM 194827; в, Nesoryzomys swarthi, male, CAS 2561, Isla Santiago; c, Megalomys desmarestii, Leiden Museum "a," Martinique; D, Megaoryzomys curioi, USNM 284318 (certain details of the palate are from USNM 284199); D', Megaoryzomys curioi, USNM 284318 (missing parts indicated by stippling, scale $1 / 2$ that of Figures $A-D)$. 

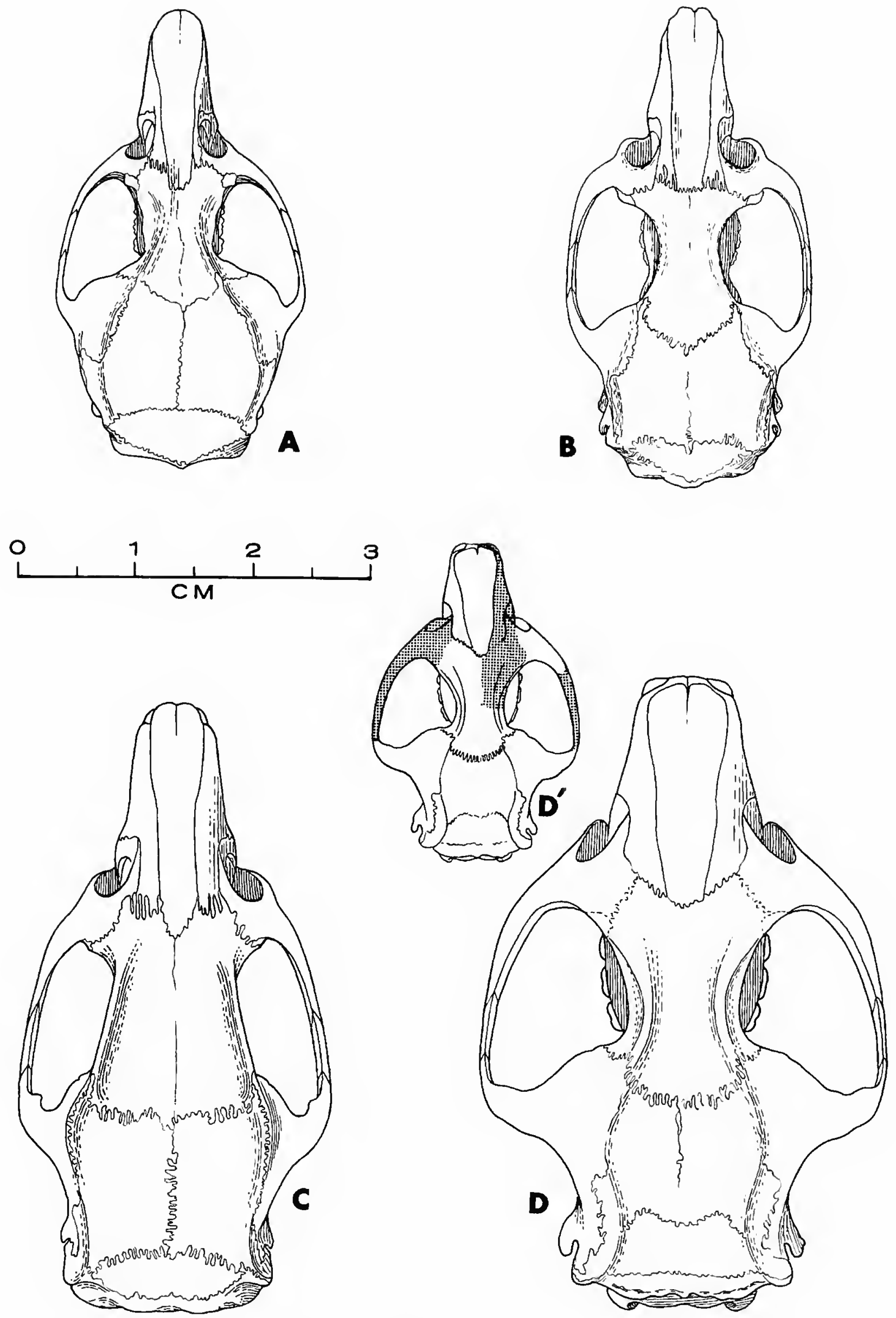

Figure 7.-Skulls in dorsal aspect: A, Thomasomys aureus, female, USNM 194827; B, Nesoryzomys swarthi, male, CAS 2561, Isla Santiago; c, Megalomys desmarestii, Leiden Museum "a," Martinique; D, Megaoryzomys curiol, USNM 284318; D', Megaoryzomys curiol, USNM 284318 (missing parts indicated by stippling, scale $1 / 2$ that of Figures A-D). 

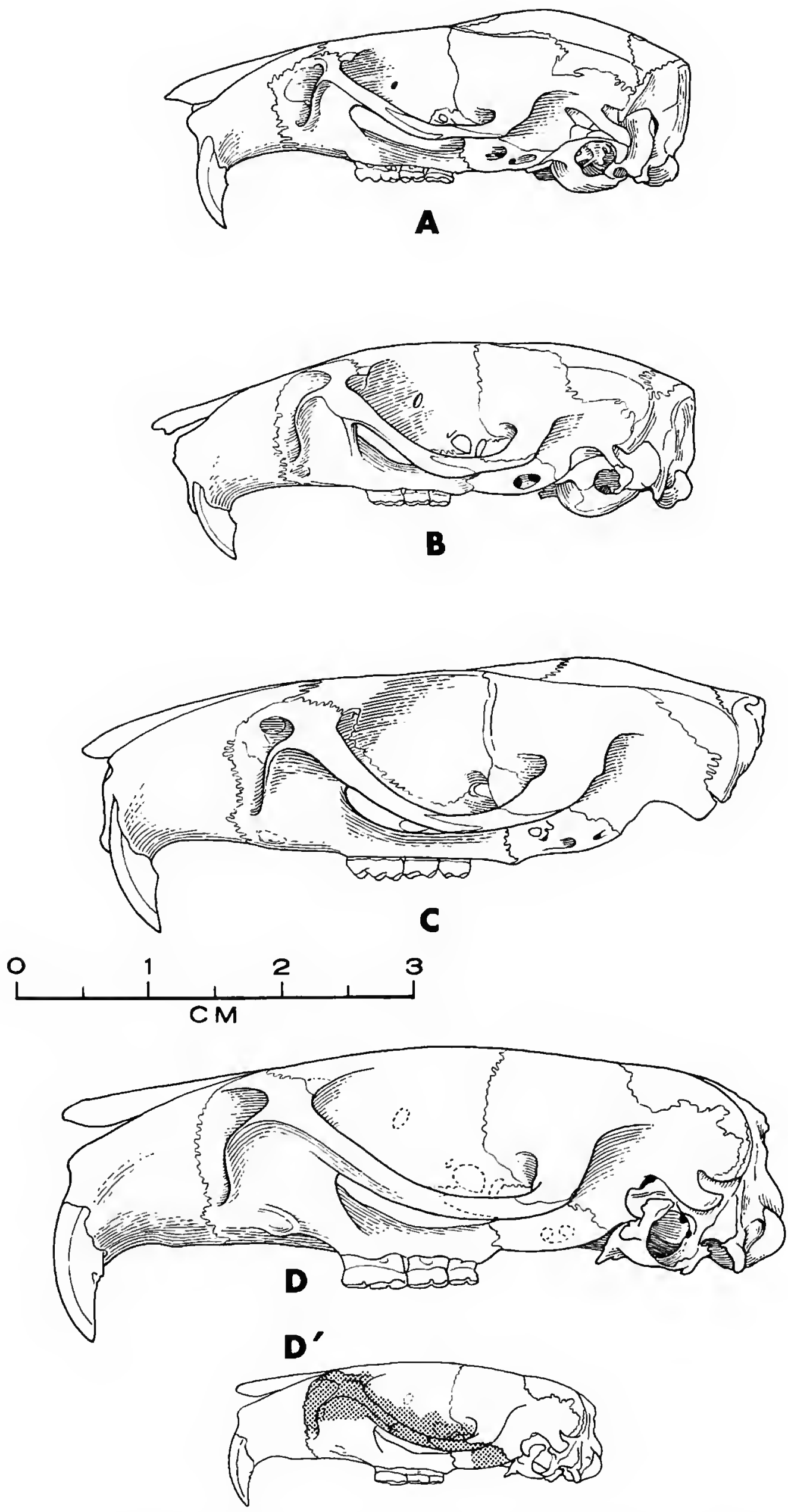

Figure 8.-Skulls in lateral aspect: A, Thomasomys aureus, female, USNM 194827; B, Nesoryzomys swarthi, male, CAS 2561, Isla Santiago; c, Megalomys desmarestii, Leiden Museum "a," Martinique; D, Megaoryzomys curioi, USNM 284318; D', Megaoryzomys curioi, USNM 284318 (missing parts indicated by stippling, scale 1/2 that of Figures A-D). 
Certain species of Thomasomys, however, are very similar to Megaoryzomys. The three largest species of Thomasomys that we examined (aureus, praetor, and princeps) show a particularly strong resemblance to Megaoryzomys. (The skull of $T$. aureus is not aberrant within Thomasomys, although Hooper and Musser (1964) regarded the phallic characters of $T$. aureus to be unlike those of other Thomasomys.) In Table 1, Megaoryzomys consistently differs from these three species of Thomasomys only in the size and number of palatal foramina. The strongly constricted interorbital region, the short and narrow palate, and the large teeth are particularly diagnostic characters of large species of Thomasomys that are also shared with Megaoryzomys, leaving little doubt that Megaoryzomys is a member of the tribe Thomasomyini. Reig (1980:263) has advocated merging the thomasomyine and oryzomyine groups, but we follow the more widely accepted arrangement at least for the present, because of the closer relationship of Thomasomys and Rhipidomys (the only other genus of living thomasomyine) to each other than to any oryzomyine.

The skull of Megaoryzomys resembles that of the larger species of Thomasomys and differs from that of Rhipidomys in its deeper depression along the sagittal suture of the frontals, its strongly constricted interorbital region (except in $R$. venezuelae), its narrow palate (except in $R$. venezuelae), its larger teeth, and its more rounded, less laterally expanded dorsolateral ridge of the braincase (except in $R$. venezuelae). Meanwhile, we can find only two characters in which Megaoryzomys resembles Rhipidomys more than Thomasomys, namely their shorter, deeper rostrum and their more angular (less-domed) braincase. The truncated, deep rostrum of Megaoryzomys and Rhipidomys is closely approached, however, by an adult and an immature specimen of Thomasomys praetor (CMNH 19255, 19256). It is unfortunate that we do not as yet have a baculum of Megaoryzomys, as its morphology in neotropical cricetines appears to have taxonomic value at both the tribal and generic levels (Hooper and Musser, 1964). We feel that Megaoryzomys is different enough from other thomasomyines to maintain its status as a separate genus, although the name Megaoryzomys is an infelicitous choice for a member of the Thomasomyini.

\section{Systematics}

Order Rodentia

Superfamily MUROIDEA

Family MURIDAE

Subfamily CricetinaE

\section{Tribe ThomasomyinI}

Osteological Diagnosis.--Small to large cricetine rodents that differ from other tribes of Cricetinae in having the following unique combination of characters: (1) short palate, (2) molars pentalophodont (fide Hershkovitz, 1962, 1967), (3) molars medium-sized to large relative to size of skull.

\section{Genus Megaoryzomys Lenglet and Coppois, 1979}

Megaoryzomys Lenglet and Coppois, 1979.

TyPe-Species.-Megalomys curioi Niethammer, 1964.

Amended Diagnosis.-Large thomasomyine rodents that differ from Thomasomys and Rhipidomys in possessing the following unique combination of characters: (1) very large size (condylobasal length of skull more than $50 \mathrm{~mm}$, zygomatic width more than $30 \mathrm{~mm}$, crown length of upper molars more than $9 \mathrm{~mm}$, length of dentary without incisor more than $30 \mathrm{~mm}$, crown length of lower molars more than $10 \mathrm{~mm}$ ), (2) deep depression along median suture of frontals (shared with certain species of Thomasomys), (3) palatal foramina large and numerous, (4) zygomatic plate of maxilla very wide, (5) zygomatic process of squamosal joining braincase at more obtuse angle, (6) braincase more rectangular (parietals flatter, less domed) in posterior aspect, (7) posterior margin of interparietal straight, (8) molars planar.

\section{Megaoryzomys curioi (Niethammer, 1964)}

Figures 3-11

Megalomys curioi Niethammer, 1964:596 [original description].

Megalomys spec. nov.-Abs et al., 1965:53.

Megaoryzomys curioi.-Lenglet and Coppois, 1979:635 [generic re-assignment]. 

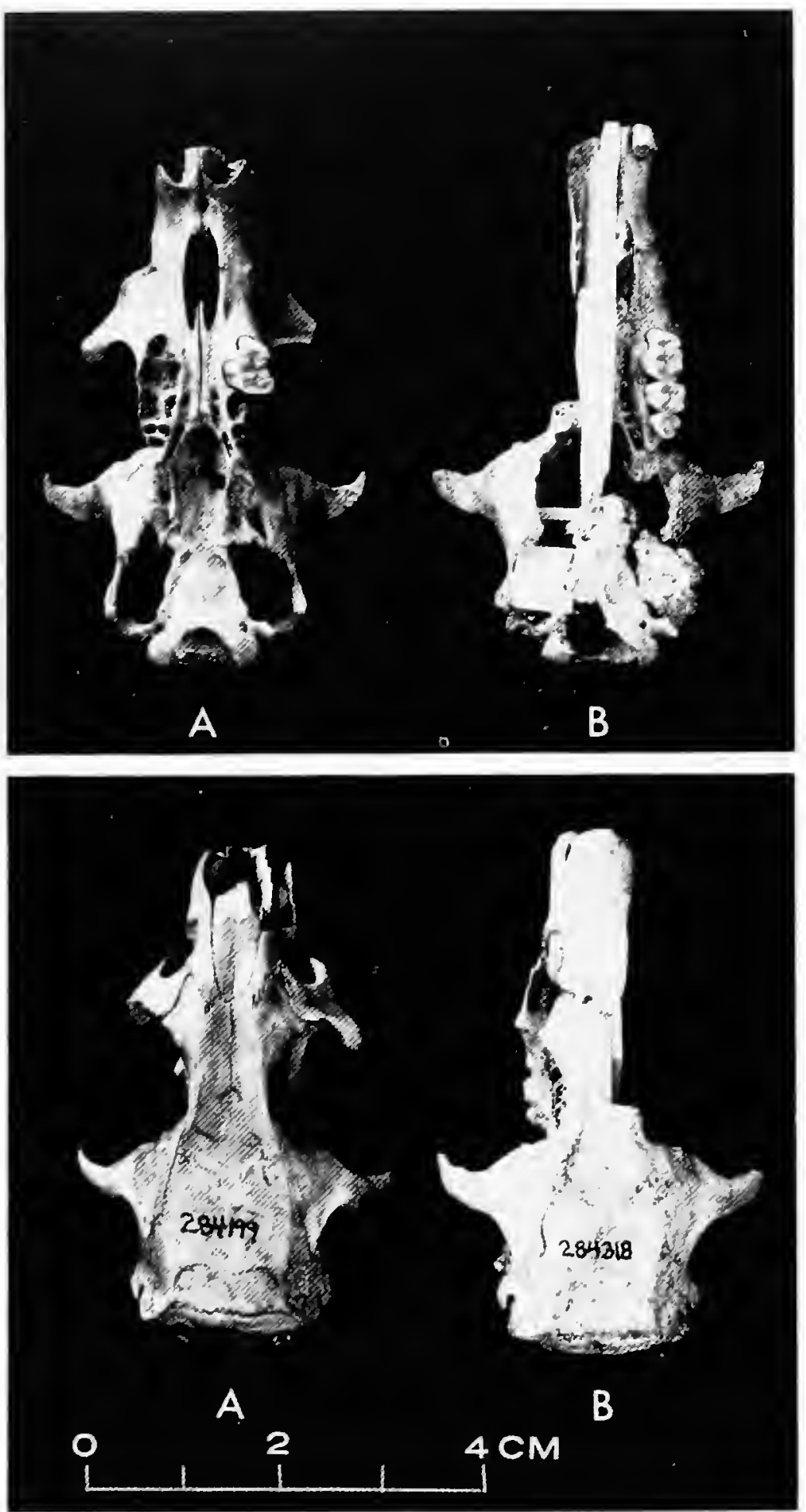

Figure 9.-Skulls of Megaoryzomys curioi from Isla Santa Cruz in dorsal and ventral aspects: A, USNM 284199; B, USNM 284318.

Holotype.-Left maxilla with $\mathrm{M}^{1-2}, \mathrm{BM}(\mathrm{NH})$ 67.1649 (Modern Mammal Section).

PARATY'PES. - A partial humerus and a partial scapula, collccted with the holotype and bearing the same catalog number.

Distribution.-Isla Santa Cruz, Galápagos, Ecuador. See Figure 2 for a map of localities.

Age.-Quaternary. Probably both Pleistocene and Holocene, but absolute age determinations are not available for sites containing Megaoryzomys.

Diagnosis. - As for the genus.

\section{Discussion}

Zoogeography: Our removal of Megaoryzomys from the tribe Oryzomyini and its placement in the Thomasomyini necessitates a reassessment of its zoogeographic implications. By showing that Megaoryzomys is not closely related to Megalomys, a genus actually confined to the West Indies, Megaoryzomys can no longer be used as evidence for the supposed high degree of faunal resemblance between the terrestrial vertebrates of Galápagos and the West Indies, an idea championed by Niethammer (1964) and many other authors, nor can one refer any longer to "the present relict Caribbean and Pacific distribution of the [giant oryzomyine] group" (Hershkovitz, 1970:794). Thus the following statements of Müller (1973:114) are untenable because of reliance on erroneous systcmatic conclusions.

The genus Megalomys was previously known only... in the Antilles... The range is therefore a relict range indicating a wider distribution in former times. The fact that the Galapagos form differs very little from those of the Antilles indicates that the Galapagos populations probably reached those islands during the Pleistocene.

Steadman (in press) has shown that proposed West Indian affinity for terrestrial organisms in Galápagos is illogical in light of the approximately synchronous emergence of the Galápagos and the Panamanian land bridge. Whereas the supposed occurrence of Megalomys in Galápagos is not supported on either a morphological or a zoogeographical basis, the relationship of Megaoryzomys to Thomasomys in fact fits perfectly into the biogeographical conclusions of Porter (1976), who refuted any supposed relationships between the floras of Galápagos and the West Indies and stated (p. 745): "The geographical evidence is overwhelming that the indigenous Galapagos flora has been derived almost totally from South America, most probably from the Andean region." 

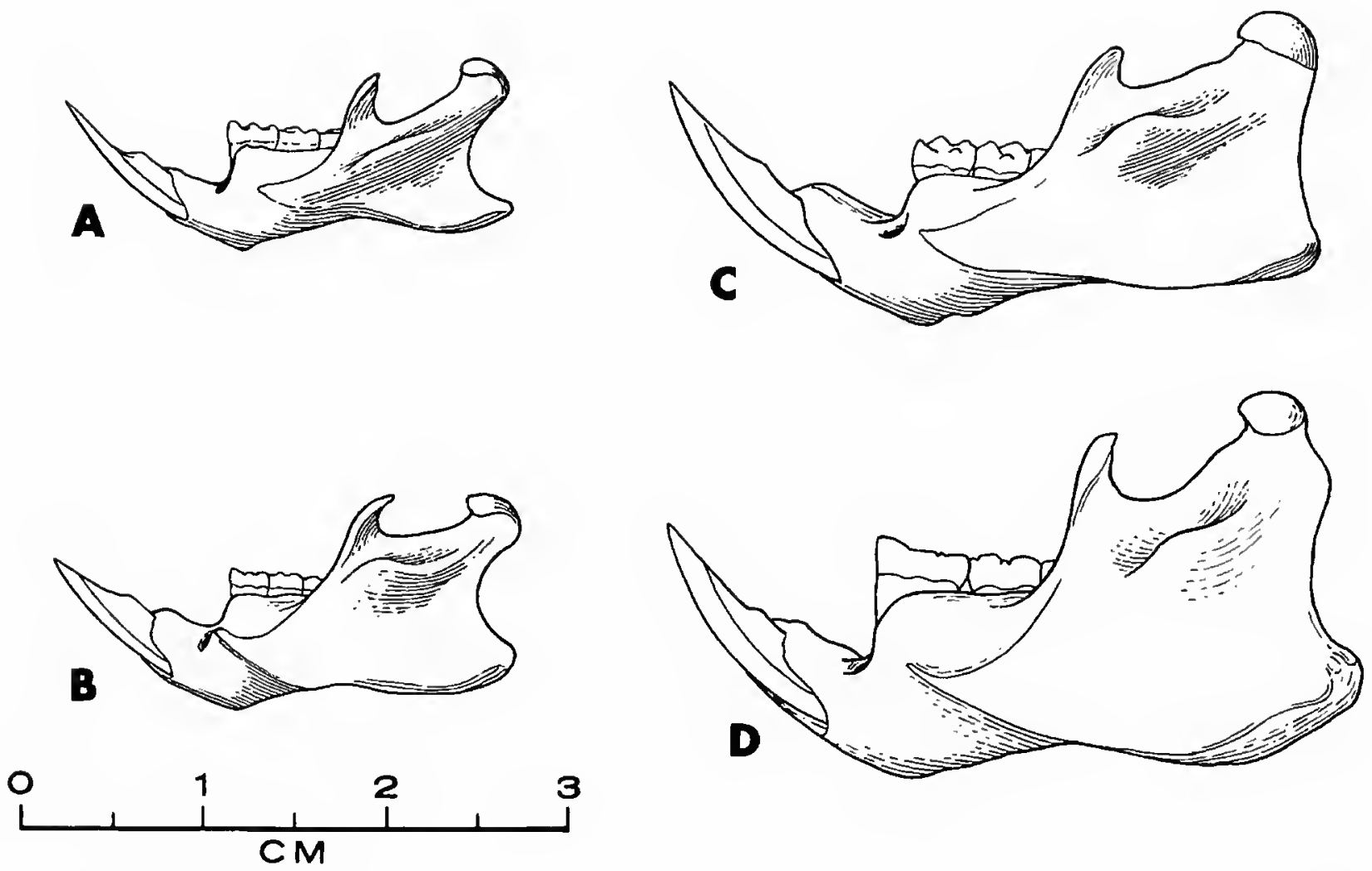

FIGURE 10.-Left dentaries in lateral aspect: A, Thomasomys aureus, female, USNM 194827; B, Nesoryzomys swarthi, male, CAS 2561, Isla Santiago; c, Megalomys desmarestii, Leiden Museum "a," Martinique; D, Megaoryzomys curioi, USNM 284290 (reversed).

Thomasomyine rodents are characterized by Hershkovitz (1972:386) as being

closely related to, but less diverse than, the oryzomyines. Some of its species are the most primitive of living myomorphs. The forms of Thomasomys are mainly terrestrialscansorial. Others, especially those of the thomasomyine genus Rhipidomys, are specialized for arboreal life.

Within the Thomasomyini, Megaoryzomys has its closest living relatives in the larger species of Thomasomys, a genus of approximately 27 species confined to South America between $8^{\circ} \mathrm{N}$ and $35^{\circ} \mathrm{S}$ latitude (Patterson and Pascual, 1972), where they inhabit forests from approximately 1200 to $4000 \mathrm{~m}$ elevation. None of the living species of Thomasomys inhabits coastal areas; however, in proposing that a species of Thomasomys was the ancestor of Megaoryzomys, we must attempt to explain how such a species reached the Pacific coast of South America. No matter which of the competing scenarios for the biogeographic and geological history of northwestern South America proves to approach reality more closely (McKenna, 1981:63, 64), it would seem that a primitive thomasomyine must have been avail- able at low elevation in the right place for early, possibly even pre-Pleistocene, colonization of Galápagos. It seems very unlikely that this was accomplished through rafting for long distances down a river from the highlands and then out to sea, such as would necessarily be the case if a species of Thomasomys were to colonize Galápagos today. Instead it seems more reasonable to suppose that a species of Thomasomys, very likely now extinct, did indeed live in the coastal lowlands of northwestern South America in the past and drifted out to Galápagos on a floating mat of vegetation. Orr (1966:280, fig. 4) figured and briefly discussed floating mats of vegetation in the Guayas River of southwestern Ecuador, and King (1962) recorded an abundance of similar rafts in the Rio Tortuguero, a sluggish stream of low gradient in Costa Rica. Mats such as these could easily support a small population of rodents for many days.

Evolution: Neither Thomasomys or Rhipidomys has a fossil record in mainland South America, so we do not know the range of morphological variation in Pleistocene thomasomyines, the probable ancestral group for Megaoryzomys. 

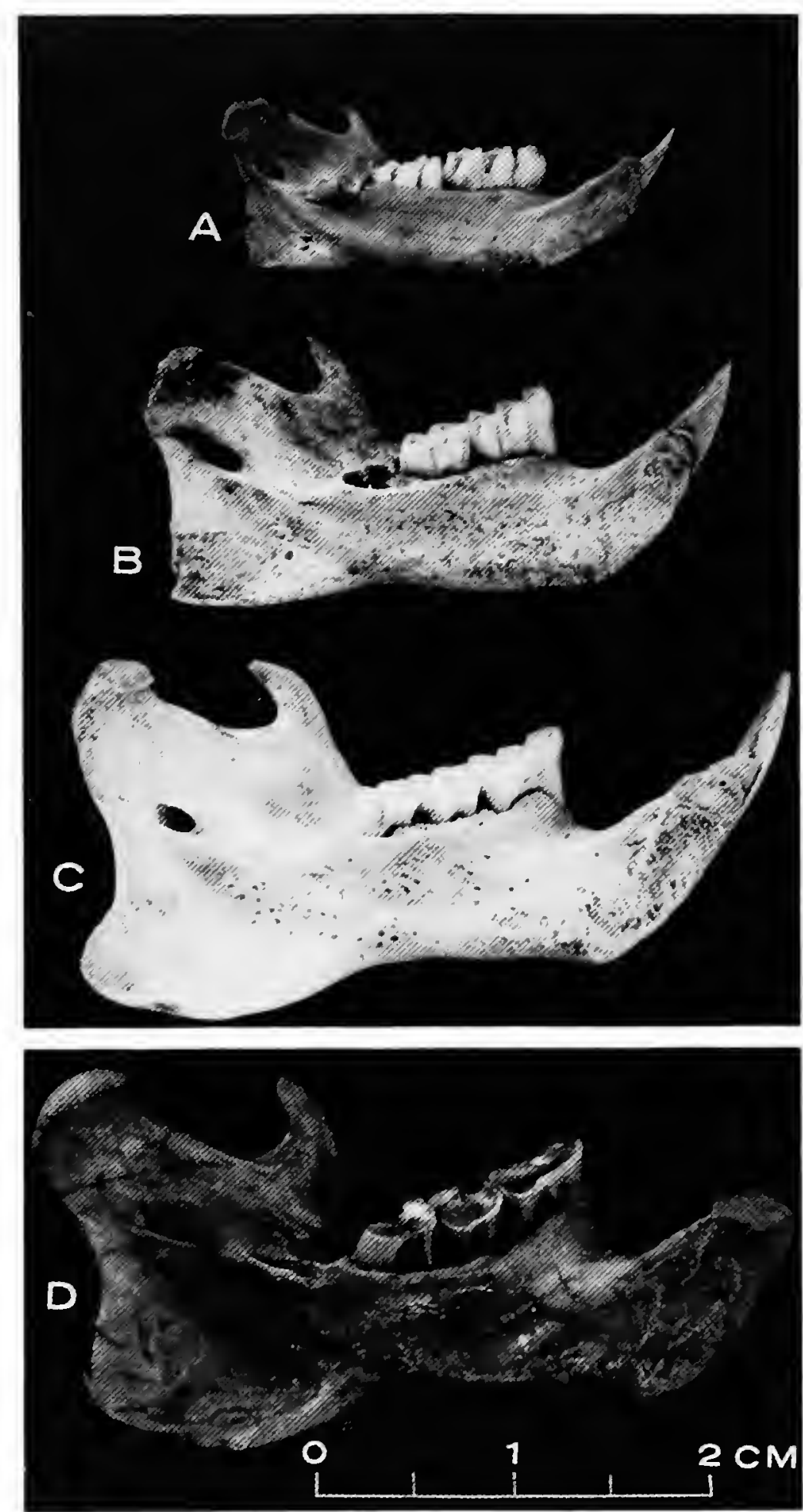

Figure 11.-Left dentaries of Megaoryzomys curioi in medial aspect: A, USNM 284207, Cueva de Kubler; B, USNM 284306, cave no. 1, place 2; c, USNM 284333, cave no. 5; D, USNM 284245, Cueva de Kubler.

Hooijer (1959, 1966) and Husson (1960) provided evidence that Thomasomys once occurred in the coastal lowlands of northern South America, where Thomasomys species is recorded in a Quaternary fossil site on the southern Caribbean island of Bonaire, near Venezuela. These specimens were more conservatively treated by Hooijer
(1967:400) as "very similar to Thomasomys, to which genus it may or may not belong." The combined effects of Plio-Pleistocene uplift of the Andes and the probable altitudinal lowering of vegetational zones during glaciation (see Simpson $1975,1979)$ give additional credibility to the suggestion that Thomasomys occurred at much lower elevations in the past than it does today. It may be noted in passing that the derivation of Megaoryzomys from Thomasomys, now restricted to higher elevations on the mainland, is analogous to the derivation of Megalomys from its close mainland relative, Macruroryzomys, now restricted to the Ecuadorean Andes (Ray, 1962; followed by Hershkovitz, 1970).

The large fossil vertebrate faunas of La Carolina, Ecuador, and Talara, Perú (Campbell, 1976, 1979, and references therein), provide evidence for the late Pleistocene existence of a more forested habitat than exists today at low elevations on the west coast of tropical South America. Certain birds at Talara are strong indicators of "at least a heavy scrub or riparian forest" (Campbell 1979:140), in an area that is extremely barren today with only widely scattered small shrubs (see figure 2 of Campbell, 1979).

The wetter, more forested conditions that existed during glacial times in coastal Perú and Ecuador are contrasted with apparent glacial aridity in Galápagos (Colinvaux 1972; Colinvaux and Schofield 1976a,b). The possible effects of these past arid conditions on the evolution and past altitudinal distribution of Megaoryzomys are difficult to state in our present lack of chronological control on its fossil sites. We do know that Megaoryzomys probably was widespread on Islas Santa Cruz and Isabela. Its known occurrences on Santa Cruz (Figure 2) range in elevation from near sea level to approximately $200 \mathrm{~m}$, and the single record of Megaoryzomys from Isabela (Figure 1) is at approximately $300 \mathrm{~m}$ elevation. This rodent therefore lived in a variety of habitats ranging from arid coastal scrub to moist highland forest. Because of the very poor preservation of bones in caves on Santa Cruz and southern Isabela that are above $300 \mathrm{~m}$ elevation (Steadman, pers. observ.), we may never know the highest 
altitudes inhabited by Megaoryzomys. The species of Thomasomys are strictly forest-dwellers, and so it may be that Megaoryzomys did not occur in the open areas of the highest regions of Santa Cruz and Isabela, where the vegetation is variously dominated by the shrub Miconia and a variety of ferns, grasses, and sedges (Wiggins and Porter, 1971).

Gigantism frequently occurs in rodents on islands, and most of the differences between Megaoryzomys and Thomasomys may be due to allometric changes associated with an increase in size. This possibility is in harmony with the closer resemblance of Megaoryzomys to the larger species of Thomasomys than to the smaller species. Insular gigantism in rodents is generally attributed to the following causes (Sondaar, 1977; Wassersug et al., 1979, and references therein): (1) predator avoidance, (2) drift toward larger size in the absence of predators because of no need to avoid them, (3) interspecific competition with other rodents, (4) selection for larger size in the absence of larger herbivores, regardless of the presence or absence of other rodents. Some combination of any of these reasons may have been involved in the attainment of large size in Megaoryzomys.

It is now apparent that Galápagos has been colonized successfully by cricetine rodents at least three different times, once by a thomasomyine and twice by oryzomyines. The colonizations that produced the endemic genera Megaoryzomys and Nesoryzomys presumably occurred much earlier than that of Oryzomys (Patton and Hafner, in press). We agree with Patton and Hafner that Nesoryzomys is best maintained as a distinct genus, at least until its relationships to mainland cricetines are resolved. Certainly Nesoryzomys is not part of the same colonization that produced Oryzomys bauri and O. galapagoensis. Cabrera (1961) and Orr (1966) regarded Nesoryzomys as a subgenus of Oryzomys, although Orr (1966) correctly noted that these taxa are very different in the shape of their interorbital regions and in their development of supraorbital ridges (see plate XxIII of Heller, 1904). In addition, the karyotypic data of Gardner and Patton (1976:20) showed Nesoryzomys to be "so aberrant chromosomally as to demand recognition as a full genus," whereas Oryzomys bauri was indistinguishable from $O$. xanthaeolus of coastal Perú. Gyldenstolpe (1932) and Patton and Hafner (in press) also noted that $O$. bauri and $O$. galapagoensis are allied to $O$. xanthaeolus. The marked similarity of $O$. bauri to $O$. galapagoensis led Cabrera (1961) and Patton and Hafner (in press) to recommend their synonymy.

Paleoecology: Niethammer (1964) indicated that both the Galápagos barn owl (Tyto punctatissima) and the short-eared owl (Asio flammeus galapagoensis) were responsible for the owl pellets associated with the three cotypes of Megaoryzomys. These pellets contained two species of bats and four species of small rodents, but Niethammer justifiably doubted that the remains of Megaoryzomys were also the remnants of owl pellets, because they represented an animal too large to be a prey item for either Tyto or Asio. Each of these owls preys heavily on rodents when available, although Tyto is much more prone to roost in caves than is Asio. Remains of Megaoryzomys also occur in caves that are not ancient roosting sites of Tyto but instead are either natural traps or simply places where Megaoryzomys died (Steadman, pers. observ.). Thus it may be that some of the fossils of Megaoryzomys in Cueva de Kubler were not prey items of Tyto. We believe that adults of Megaoryzomys could have been prey items of Tyto punctatissima only if they were killed and eaten within the roosting cave, whereas small, young individuals of Megaoryzomys apparently were preyed upon more frequently than adults and were not necessarily taken within a cave.

Extinction: The chronology of extinction of Megaoryzomys is very speculative. There are no absolute age determinations available as yet for any mammal-bearing fossil deposit in Galápagos, although this situation may be remedied soon by several radiocarbon samples (carbonized wood) from Gueva de Kubler that have been submitted for age determination. Both Nesoryzomys indefessus and $N$. darwini survived until 1935-1945 on Isla Santa Cruz (Eckhardt, 1972), although they are now presumed to be extinct through predation by introduced mammals or competition from the introduced black rat, Rattus rattus (Brosset, 1963; 
Niethammer, 1964; Clark, 1981), which did not reach Santa Cruz until the 1930's or 1940's (Eckhardt, 1972; Patton et al., 1975). If Rattus or other introduced mammals had also recently caused the extinction of Megaoryzomys, it seems inexplicable that such a large rodent would have escaped the notice of sailors, explorers, residents, and scientific collectors who have combed Santa Cruz for the past 100 years. Thus it seems likely that Megaoryzomys became extinct before the other native rodents died out on Santa Cruz, even though we cannot yet assign an age to this event.

We have no evidence of contemporaneity of Megaoryzomys and Rattus. Niethammer (1964) noted that the bones of Megaoryzomys from the type-locality were not in the form of owl pellets as were those of Rattus and Nesoryzomys. In addition, these remains of Megaoryzomys gave Niethammer the impression of being older than those of the other rodents, as he stated (1964:605): "Presumably, the remains [of Megaoryzomys] were of a more remote origin than the recent pellets with which they might have been mixed by pure chance [our translation]." Megaoryzomys occurs in excavations IIB and IIC of Cueva de Kubler, where the sediments also contain bones of introduced Rattus and mice (Mus musculus), with much more numerous fossils of a large and small species of Nesoryzomys (probably $N$. indefessus and $N$. darwini, respectively). Although all five species of rodents may occur at the same stratigraphic levels in the unlaminated, loose cave sediments of Cueva de Kubler, the bones of Rattus and Mus are less mineralized, much lighter in color, and therefore apparently significantly younger than those of Nesoryzomys or Megaoryzomys (Steadman, 1981).

Bones of Megaoryzomys occur commonly on the surfaces of floors of lava tubes, small rock shelters, and ledges on the walls of fissures, suggesting to us that Megaoryzomys became extinct probably within the past several centuries. The possibility of the involvement of feral dogs, cats, and pigs in the extinction of Megaoryzomys, as stated by Niethammer (1964), is also suggestive of a recent extinction. Slevin (1959:7) listed dogs, cats, pigs, and burros as the introduced mammals of Santa
Cruz, exclusive of rodents. Eckhardt (1972) added goats and cattle to this list. Steadman has seen dogs, cats, rats, mice, goats, pigs, cattle, and burros on Santa Cruz from 1978 to 1981, with the first four species very common at least locally. Nearly all of these animals became established only after the initial period of human settlement on Santa Cruz, placed at early in the 20th century by Slevin (1959:108). It is not difficult to imagine how people and feral dogs, cats, rats, and pigs could devastate the population of a large rodent that evolved in the absence of mammalian predators and that, like the other vertebrates of Galápagos, would not have been wary when approached by an alien mammal.

Rattus has lived on Isla Isabela for a longer time than on Santa Gruz; the first definite record of any rodent on Isabela is that of a specimen of Rattus taken in 1891 by G. Baur (Allen, 1892). Charles Darwin did not mention the presence of Rattus or any other rodent on Isabela during his brief visit there in 1835 (Patton et al., 1975), although he noted Oryzomys galapagoensis on San Cristóbal and Rattus on Santiago. According to Slevin (1959:107) the first permanent human settlement of Isabela occurred in 1893 with the establishment of the villages of Villamil on the southern coast and Santo Tomás in the southern highlands. Thus 1893 is the last probable date for the establishment on Isabela of many of its feral mammals, which include dogs, cats, cattle, and burros (Slevin, 1959:7). It seems reasonable to suggest that Megaoryzomys species became extinct on Isabela within the past two centuries, unnoticed by man. As noted by Heller (1904), the fact that no species of Nesoryzomys has been recorded living on Isabela (members of this genus occur on Santa Cruz, Baltra, Santiago, and Fernandina) strongly suggests an early colonization of Isabela by Rattus and resultant extinction of Nesoryzomys prior to any thorough scientific surveys. This suggestion has recently been confirmed by Steadman's field work on Isabela in 1980, which produced remains of a small species of Nesoryzomys as well as additional material of Megaoryzomys. This material will be treated in detail in another paper. 


\section{Literature Cited}

Abs, M., E. Curio, P. Kramer, and J. Niethammer

1965. Zur Ernährungsweise der Eulen auf Galapagos: Ergebnisse der Deutschen Galapagos-Expedition 1962/63, IX. Journal für Omithologie, 106(1):49-57, 2 tables.

Allen, J.A.

1892. On a Small Collection of Mammals from the Galapagos Islands, Collected by Dr. G. Baur. Bulletin of the American Museum of Natural History, 4:4750.

Berry, R.J.

1964. The Evolution of an Island Population of the House Mouse. Evolution, 18(3):468-483, 3 figures, 7 tables.

1981. Town Mouse, Country Mouse: Adaptation and Adaptability in Mus domesticus (M. musculus domesticus). Mammal Review, 11(3):91-136, 10 figures, 17 tables.

Brosset, A.

1963. Statut Actuel des Mammiferes des ̂̂les Galapagos. Mammalia, 27(3):323-338, plate 12.

Cabrera, A.

1961. Catálogo de los Mamíferos de América del Sur, II (Sirenia-Perissodactyla-Artiodactyla-LagomorphaRodentia-Cetacea). Revista del Museo Argentino de Ciencias Naturales "Bernardino Rivadavia" e Instituto Nacional de Investigación de las Ciencias Naturales, Ciencias Zoológicas, 4(2): xxil + pages 309-732, frontispiece.

Campbell, K.E., Jr.

1976. The Late Pleistocene Avifauna of La Carolina, Southwestern Ecuador. In S.L. Olson, editor, Collected Papers in Avian Paleontology Honoring the 90th Birthday of Alexander Wetmore. Smithsonian Contributions to Paleobiology, 27:155-168, 3 figures, 2 tables.

1979. The Non-Passerine Pleistocene Avifauna of the Talara Tar Seeps, Northwestern Peru. Life Sciences Contributions, Royal Ontario Museum, 118: 203 pages, 31 figures, 12 tables.

Clark, D.A.

1981. Foraging Patterns of Black Rats across a DesertMontane Forest Gradient in the Galápagos Islands. Biotropica, 13(3): 182-194, 4 figures, 3 tables.

Colinvaux, P.A.

1972. Climate and the Galapagos Islands. Nature, 240(5375): 17-20, 3 figures.
Colinvaux, P.A., and E.K. Schofield

1976a. Historical Ecology in the Galápagos Islands, I: A Holocene Pollen Record from El Junco Lake, Isla San Cristobal. Joumal of Ecology, 64(3):989-1012, 6 figures, 5 tables.

1976b. Historical Ecology in the Galápagos Islands, II: A Holocene Spore Record from El Junco Lake, Isla San Cristobal. Journal of Ecology, 64(3): 1013-1026, 3 figures, 2 plates, 1 table.

Crusafont-Pairo, M., and F. Petter

1964. Un Muriné géanı fossile des Iles Canaries, Canariomys bravoi Gen. Nov.. Sp. Nov. (Rongeurs, Muridés). Mammalia, 28(4):607-612, 1 figure.

Eckhardt, R.C.

1972. Introduced Plants and Animals in the Galápagos Islands. BioScience, 22(10):585-590, 3 figures, 1 table.

Foster, J.B.

1964. Evolution of Mammals on Islands. Nature, 202(4929):234, 235, 1 table.

Gardner, A.L., and J.L. Patton

1976. Karyotypic Variation in Oryzomyine Rodents (Cricetinae) with Comments on Chromosomal Evolution in the Neotropical Cricetine Complex. Occasional Papers of the Museum of Zoology, Louisiana State University, 49: 48 pages, 10 figures, 2 tables.

Gill, A.E.

1980. Evolutionary Genetics of California Islands Peromyscus. In D.M. Power, editor, The Califormia Islands: Proceedings of a Multidisciplinary Symposium, pages 719-743, 1 figure, 10 tables. Santa Barbara, California: Santa Barbara Museum of Natural History.

Gyldenstolpe, N.

1932. A Manual of Neotropical Sigmodont Rodents. Kungliga Suenska Vetenskapsakademiens Handlingar, third series, 11(3): 164 pages, 18 plates, tables.

Heller, E.

1904. Mammals of the Galapagos Archipelago, Exclusive of the Cetacea. In Papers from the Hopkins Stanford Galapagos Expedition, 1898-1899. Proceedings of the Califormia Academy of Sciences, third series (Zoology), 3(7):233-249, plate 23, tables.

Hershkovitz, P.

1962. Evolution of Neotropical Cricetine Rodents (Muridae) with Special Reference to the Phyllotine 
Group. Fieldiana, Zoology, 46: 524 pages, 123 figures, 66 tables.

1967. Dynamics of Rodent Molar Evolution: A Study Based on New World Cricetinae, Family Muridae. Journal of Dental Research, 46(5) (part 1, supplement):829-842, 8 figures.

1970. Supplementary Notes on Neotropical Oryzomys dimidiatus and Oryzomys hammondi (Cricetinae). Journal of Mammalogy, 51(4):789-794, 2 figures, 2 tables.

1972. The Recent Mammals of the Neotropical Region: A Zoogeographic and Ecological Review. In A. Keast, F.C. Erk, and B. Glass, editors, Evolution, Mammals, and Southern Continents, pages 311-431, 16 figures, 6 tables. Albany: State University of New York Press.

Hooijer, D.A.

1959. Fossil Rodents from Curaçao and Bonaire. Studies on the Fauna of Curaçao and Other Caribbean Islands, 9(35): 27 pages, 1 unnumbered figure, 3 plates, 10 tables.

1966. Fossil Mammals of the Netherlands Antilles. $A r-$ chives Néerlandaises de Zoologie, 16(4):531, 532.

1967. Pleistocene Vèrtebrates of the Netherlands Antilles. In P.S. Martin and H.E. Wright, Jr., editors, Pleistocene Extinctions: The Search for a Cause, pages 399-406, 1 figure. New Haven: Yale University Press.

Hooper, E.T., and G.G. Musser

1964. The Glans Penis in Neotropical Cricetines (Family Muridae) with Comments on Classification of Muroid Rodents. Miscellaneous Publications, Museum of Zoology, University of Michigan, 123: 57 pages, 9 figures, 2 tables.

Husson, A.M.

1960. De Zoogdieren van de Nederlandse Antillen. [Mammals of the Netherlands Antilles.] Uitgaven van de Natuurwetenschappelijke Werkgroep Nederlandse Antillen, Curaçao, 12: 170 pages, 27 figures, 42 plates, tables. [In Dutch; English summary on pages 143-170.]

Hutterer, R., and U. Hirsch

1979. Ein neuer Nesoryzomys von der Insel Fernandina, Galápagos (Mammalia, Rodentia). Bonner Zoologische Beiträge, 30(3-4):276-283, 3 figures, 1 table.

King, $W$.

1962. The Occurrence of Rafts for Dispersal of Land Animals into the West Indies. Quarterly Joumal of the Florida Academy of Sciences, 25(1):45-52, 1 table.

Lenglet, G., and G. Coppois

1979. Description du crâne et de quelques ossements d'un genre nouveau éteint de Cricetidae (Mammalia-Rodentia) géant des Galapagos: Megaoryzomys (gen. nov.). Bulletin de l'Académie Royale de
Belgique (Classe des Sciences), fifth series, 65 (11):632-648, 7 figures, 2 plates, 5 tables.

McKenna, M.C.

1981. Early History and Biogeography of South America's Extinct Land Mammals. In R.L. Ciochon and A.B. Chiarelli, editors, Evolutionary Biology of the New World Monkeys and Continental Drift, pages 43-77. New York and London: Plenum Press.

Müller, P.

1973. The Dispersal Centres of Terrestrial Vertebrates in the Neotropical Realm. Biogeographica, 2: 244 pages. The Hague: W. Junk.

Musser, Guy G.

1981. The Giant Rat of Flores and Its Relatives East of Borneo and Bali. Bulletin of the American Museum of Natural History, 169(2):67-176, figures 1-40, tables 1-16.

Niethammer, J.

1964. Contribution a la connaissance des mammiferes terrestres de l'île Indefatigable (= Santa Cruz), Galapagos. Mammalia, 28(4):593-606, 4 figures, 4 tables.

Orr, R.T.

1966. Evolutionary Aspects of the Mammalian Fauna of the Galápagos. In R.I. Bowman, editor, The Galápagos: Proceedings of the Symposia of the Galápagos International Scientific Project, pages 276-281, figures 1-4. Berkeley: University of California Press. Brussels: Palais des Academies.

Patterson, B., and R. Pascual

1972. The Fossil Mammal Fauna of South America. In A. Keast, F.C. Erk, and B. Glass, editors, Evolution, Mammals, and Southern Continents, pages 247-309, 13 figures, 12 tables. Albany: State University of New York Press.

Patton, J.L., and M.S. Hafner

In press. Biosystematics of the Native Rodents of the Galápagos Archipelago, Ecuador. In R.I. Bowman and A.E. Leviton, editors, Palterns of Evolution in Galápagos Organisms. San Francisco: American Associalion for the Advancement of Science, Pacific Division.

Patton, J.L., S.Y. Yang, and P. Myers

1975. Genetic and Morphologic Divergence among Introduced Rat Populations (Raltus rattus) of the Galápagos Archipelago, Ecuador. Systematic Zoology, 24(3):296-310, 2 figures, 7 tables.

Peterson, R.L.

1966. Recent Mammal Records from the Galapagos Islands. Mammalia, 30(3):441-445, plate 25, 2 tables.

Petronio, C.

1970. I Roditori Pleistocenici della Grotta di Spinagallo 
(Siracusa). Geologica Romana, 9:149-194, 28 figures, 6 plates, tables.

Porter, D.M.

1976. Geography and Dispersal of Galapagos Islands Vascular Plants. Nature, 264(5588):745, 746, 2 tables.

Ray, C.E.

1962. Oryzomyine Rodents of the Antillean Subregion. 356 pages, 30 figures, 41 tables. Doctoral dissertation, Harvard University, Cambridge, Massachusetts.

Ray, C.E., and F.C. Whitmore, Jr.

1973. Paleontology. In T. Simkin, W.G. Reeder, and C. MacFarland, editors, Galápagos Science: 1972 Status and Needs, pages 67, 68. Washington, D.C. [Printed for the Smithsonian Institution; sponsored by the National Science Foundation and the University of Wisconsin.]

Reig, O.A.

1980. A New Fossil Genus of South American Cricetid Rodents Allied to Wiedomys, with an Assessment of the Sigmodontinae. Journal of Zoology, London, 192(2):257-281, 4 figures, 2 tables.

Simpson, B.B.

1975. Pleistocene Changes in the Flora of the High Tropical Andes. Paleobiology, 1(3):273-294, 20 figures, 5 tables.

1979. Quaternary Biogeography of the High Montane Regions of South America. In W.E. Duellman, editor, The South American Herpetofauna: Its Origin, Evolution, and Dispersal. Monograph of the Museum of Natural History, University of Kansas, 7:157-188, 8 figures.

Slevin, J.R.

1959. The Galápagos Islands: A History of Their Exploration. Occasional Papers of the California Academy of Sciences, 25: $\mathrm{x}+150$ pages, 31 figures.
Sondaar, P.Y.

1977. Insularity and Its Effect on Mammal Evolution. In M.K. Hecht, P.C. Goody, and B.M. Hecht, editors, Major Patterns in Vertebrate Evolution, pages 671-707, 10 figures, 1 table. New York: Plenum Press. [NATO Advanced Study Institutes series, volume 14.]

Steadman, D.W.

1981. Vertebrate Fossils in Lava Tubes in the Galápagos Islands. In B.F. Beck, editor, Proceedings of the Eighth International Congress of Speleology, Volume II, pages 549, 550. Americus: Georgia Southwestern College.

In press. The Origin of Darwin's Finches. Transactions of the San Diego Society of Natural History, 19.

Thomas, O.

1905. Suggestions for the Nomenclature of the Cranial Length Measurements and of the Cheek-Teeth of Mammals. Proceedings of the Biological Society of Washington, 18 (34):191-196, 1 figure.

Varona, L.S.

1974. Catálogo de los Mamíferos Vivientes y Extinguidos de las Antillas. 139 pages, map. Havana: Academia de Ciencias de Cuba.

Walker, P.L.

1980. Archaeological Evidence for the Recent Extinction of Three Terrestrial Mammals on San Miguel Island. In D.M. Power, editor, The California Islands: Proceedings of a Multidisciplinary Symposium, pages 703-717, 4 figures, 5 tables. Santa Barbara, California: Santa Barbara Museum of Natural History.

Wassersug, R.J., H. Yang, J.J. Sepkoski, Jr., and D.M. Raup 1979. The Evolution of Body Size on Islands: A Computer Simulation. The American Naturalist, 114(2):287-295, 4 figures.

Wiggins, I.L., and D.M. Porter, editors

1971. Flora of the Galapagos Islands. 998 pages, 268 figures, 96 plates, 2 tables. Stanford, California: Stanford University Press. 



\section{REQUIREMENTS FOR SMITHSONIAN SERIES PUBLICATION}

Manuscripts intended for series publication receive substantive review within their originating Smithsonian museums or offices and are submitted to the Smithsonian Institution Press with approval of the appropriate museum authority on Form S1-36. Requests for special treatment-use of color, foldouts, casebound covers, etc.-require, on the same form, the added approval of designated committees or museum directors.

Review of manuscripts and art by the Press for requirements of series format and style, completeness and clarity of copy, and arrangement of all material, as outlined below, will govern, within the judgment of the Press, acceptance or rejection of the manuscripts and art.

Copy must be typewritten, double-spaced, on one side of standard white bond paper, with $1 \frac{1}{4}$ " margins, submitted as ribbon copy (not carbon or xerox), in loose sheets (not stapled or bound), and accompanied by original art. Minimum acceptable length is 30 pages.

Front matter (preceding the text) should include: title page with only title and author and no other information, abstract page with author/title/series/etc., following the established format, table of contents with indents reflecting the heads and structure of the paper.

First page of text should carry the title and author at the top of the page and an unnum. bered footnote at the bottom consisting of author's name and professional mailing address.

Center heads of whatever level should be typed with initial caps of major words, with extra space above and below the head, but with no other preparation (such as all caps or underline). Run-in paragraph heads should use period/dashes or colons as necessary.

Tabulations within text (lists of data, often in parallel columns) can be typed on the text page where they occur, but they should not contain rules or formal, numbered table heads.

Formal tables (numbered, with table heads, boxheads, stubs, rules) should be submitted as camera copy, but the author must contact the series section of the Press for editorial attention and preparation assistance before final typing of this matter.

Taxonomic keys in natural history papers should use the alined-couplet form in the zoology and paleobiology series and the multi-level indent form in the botany series. If cross-referencing is required between key and text, do not include page references within the key, but number the keyed-out taxa with their corresponding heads in the text.

Synonymy in the zoology and paleobiology series must use the short form (taxon, author, year:page), with a full reference at the end of the paper under "Literature Cited." For the botany series, the long form (taxon, author, abbreviated journal or book title, volume, page, year, with no reference in the "Literature Cited") is optional.

Footnotes, when few in number, whether annotative or bibliographic, should be typed at the bottom of the text page on which the reference occurs. Extensive notes must appear at the end of the text in a notes section. If bibliographic footnotes are required, use the short form (author/brief title/page) with the full reference in the bibliography.

Text-reference system (author/year/page within the text, with the full reference in a "Literature Cited" at the end of the text) must be used in place of bibliographic footnotes in all scientific series and is strongly recommended in the history and technology series: "(Jones, 1910:122)" or ". . Jones (1910:122)."

Bibliography, depending upon use, is termed "References," "Selected References," or "Literature Cited." Spell out book, journal, and article titles, using initial caps in all major words. For capitalization of titles in foreign languages, follow the national practice of each language. Underline (for italics) book and journal titles. Use the colon-parentheses system for volume/number/page citations: "10(2):5-9." For alinement and arrangement of elements, follow the format of the series for which the manuscript is intended.

Legends for illustrations must not be attached to the art nor included within the text but must be submitted at the end of the manuscript-with as many legends typed, doublespaced, to a page as convenient.

Illustrations must not be included within the manuscript but must be submitted separately as original art (not copies). All illustrations (photographs, line drawings, maps, etc.) can be intermixed throughout the printed text. They should be termed Figures and should be numbered consecutively. If several "figures" are treated as components of a single larger figure, they should be designated by lowercase italic letters (underlined in copy) on the illustration, in the legend, and in text references: "Figure 9b." If illustrations are intended to be printed separately on coated stock following the text, they should be termed Plates and any components should be lettered as in figures: "Plate 9. $\underline{b} . "$ Keys to any symbols within an illustration should appear on the art and not in the legend.

A few points of style: (1) Do not use periods after such abbreviations as " $\mathrm{mm}$, $\mathrm{ft}$, yds, USNM, NNE, AM, BC." (2) Use hyphens in spelled-out fractions: "two-thirds." (3) Spell out numbers "one" through "nine" in expository text, but use numerals in all other cases if possible. (4) Use the metric system of measurement, where possible, instead of the English system. (5) Use the decimal system, where possible, in place of fractions. (6) Use day/month/year sequence for dates: "9 April 1976." (7) For months in tabular listings or data sections, use three-letter abbreviations with no periods: "Jan, Mar, Jun," etc.

Arrange and paginate sequentially EVERY sheet of manuscript-including ALL front matter and ALL legends, etc., at the back of the text-in the following order: (1) title page, (2) abstract, (3) table of contents, (4) foreword and/or preface, (5) text, (6) appendixes, (7) notes, (8) glossary, (9) bibliography, (10) index, (11) legends. 


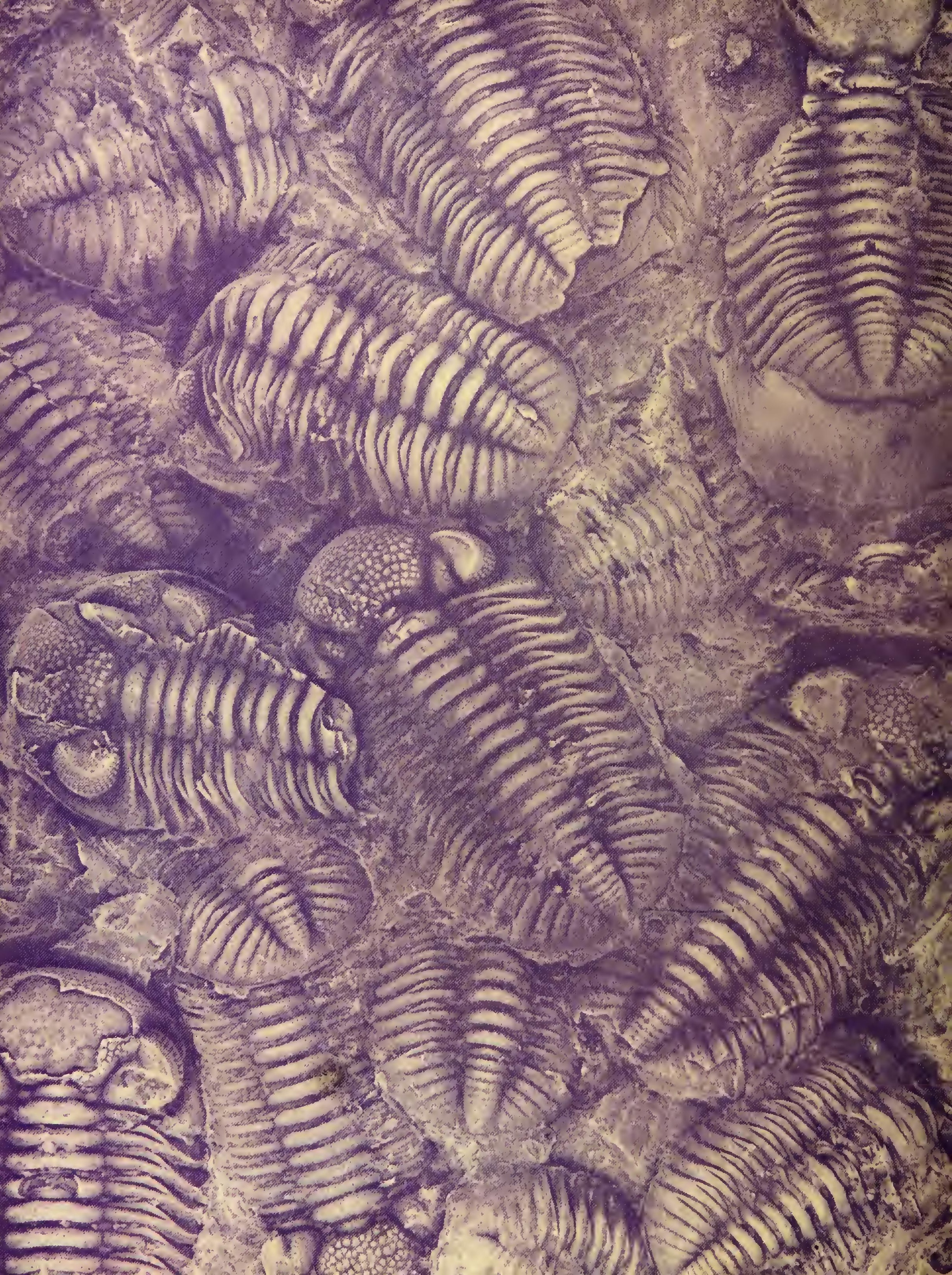

